\title{
Mutant p53 gain of function can be at the root of dedifferentiation of human osteosarcoma MG63 cells into 3AB-OS cancer stem cells
}

\author{
Riccardo Di Fiore a , Michela Marcatti ${ }^{\text {a }}$, Rosa Drago-Ferrante ${ }^{\mathrm{a}}$, Antonella D'Anneo ${ }^{\mathrm{a}}$, Michela Giuliano ${ }^{\mathrm{a}}$, \\ Daniela Carlisi ${ }^{\mathrm{b}}$, Anna De Blasio ${ }^{\mathrm{a}}$, Francesca Querques ${ }^{\mathrm{c}, \mathrm{d}}$, Lucio Pastore ${ }^{\mathrm{c}, \mathrm{d}}$, \\ Giovanni Tesoriere ${ }^{\mathrm{e}}$, Renza Vento ${ }^{\mathrm{a}, \mathrm{e}, *}$ \\ a Laboratory of Biochemistry, Department of Biological, Chemical and Pharmaceutical Sciences and Technologies, University of Palermo, Polyclinic, Palermo, Italy \\ ${ }^{\mathrm{b}}$ Laboratory of Biochemistry, Department of Experimental Biomedicine and Clinical Neurosciences, University of Palermo, Polyclinic, Palermo, Italy \\ c Department of Molecular Medicine and Medical Biotechnology, University of Naples "Federico II," Naples, Italy \\ d CEINGE-Advanced Biotechnology s.c.a.r.l., Naples, Italy \\ e Institute for Cancer Research and Molecular Medicine and Center of Biotechnology, College of Science and Biotechnology, Temple University, Philadelphia, PA, USA
}

\section{A R T I C L E I N F O}

\section{Article history:}

Received 31 July 2013

Revised 25 November 2013

Accepted 17 December 2013

Available online 27 December 2013

Edited by: Michael Amling

\section{Keywords:}

Human osteosarcoma

Cancer stem cells

Mutant p53 gain of function

Cancer cell dedifferentiation

3AB-OS cells

\begin{abstract}
A B S T R A C T
Osteosarcoma is a highly metastatic tumor affecting adolescents, for which there is no second-line chemotherapy. As suggested for most tumors, its capability to overgrow is probably driven by cancer stem cells (CSCs), and finding new targets to kill CSCs may be critical for improving patient survival. TP53 is the most frequently mutated tumor suppressor gene in cancers and mutant p53 protein (mutp53) can acquire gain of function (GOF) strongly contributing to malignancy. Studies thus far have not shown p53-GOF in osteosarcoma. Here, we investigated TP53 gene status/role in 3AB-OS cells-a highly aggressive CSC line previously selected from human osteosarcoma MG63 cells-to evaluate its involvement in promoting proliferation, invasiveness, resistance to apoptosis and stemness. By RT-PCR, methylation-specific PCR, fluorescent in situ hybridization, DNA sequence, western blot and immunofluorescence analyses, we have shown that-in comparison with parental MG63 cells where TP53 gene is hypermethylated, rearranged and in single copy-in 3AB-OS cells, TP53 is unmethylated, rearranged and in multiple copies, and mutp53 (p53-R248W/P72R) is post-translationally modified and with nuclear localization. p53-R248W/P72R-knockdown by short-interfering RNA reduced the growth and replication rate of 3AB-OS cells, markedly increasing cell cycle inhibitor levels and sensitized 3AB-OS cells to TRAILinduced apoptosis by DR5 up-regulation; moreover, it strongly decreased the levels of stemness and invasiveness genes. We have also found that the ectopic expression of p53-R248W/P72R in MG63 cells promoted cancer stemlike features, as high proliferation rate, sphere formation, clonogenic growth, high migration and invasive ability; furthermore, it strongly increased the levels of stemness proteins. Overall, the findings suggest the involvement of p53-R248W/P72R at the origin of the aberrant characters of the 3AB-OS cells with the hypothesis that its GOF can be at the root of the dedifferentiation of MG63 cells into CSCs.
\end{abstract}

(C) 2013 Elsevier Inc. All rights reserved.

\section{Introduction}

Osteosarcoma (OS), the most common malignant bone tumor in adolescents and young adults, is a highly aggressive tumor exhibiting clinical, histologic and molecular heterogeneity [1]. The current standard chemotherapy regimen, which includes cisplatin, doxorubicin and methotrexate, provides only 65-70\% long-term disease-free survival for OS patients without metastasis [2], and there is no established second-line chemotherapy for relapsed OS; thus, the identification of

Abbreviations: CSCs, Cancer stem cells; FISH, Fluorescent in situ hybridization; GOF, Gain of function; MMPs, Matrix metalloproteinases; Mutp53, Mutant p53; OS, Osteosarcoma.

* Corresponding author at: University of Palermo, Polyclinic, via del Vespro 129, 90127 Palermo, Italy.

E-mail address: renza.vento@unipa.it (R. Vento). new therapeutic strategies to improve the clinical outcome of these patients is urgent.

It is well known that most solid tumors contain a distinct subpopulation of cancer stem cells (CSCs), which represent the source for tissue renewal, hold malignant potential and can be responsible for therapy resistance [3-6], and it has been suggested that a successful cure of cancer should requires eradication of CSCs [7-9].

Previously, we have demonstrated that the short-term treatment of human OS MG63 cells with 3-aminobenzamide (3AB), a potent inhibitor of the chromatin remodelling enzyme poly(ADP-ribose)polymerase, induced morphological and biochemical features of osteocyte differentiation, accompanied by the down-regulation of gene products required for proliferation and the up-regulation of those implicated in osteoblast differentiation [10]. However, prolonged treatment (about 100 days) of MG63 cells with $3 \mathrm{AB}$ induced osteocyte death accompanied by progressive 
enrichment of a new heterogeneous and stable cell population termed $3 \mathrm{AB}-\mathrm{OS}$ [11], which have properties (self-renewal and pluripotency in vitro, tumorigenicity in vivo) that indicated them as CSCs $[12,13]$ and allowed their patenting. 3AB-OS cells have been characterized at genetic and molecular level: compared to parental MG63 cells, which have a hypotriploid karyotype with chromosome number ranging from 61 to 66 , they are hypertriploid with chromosome number ranging from 71 to 82; they also exhibit 49 copy number variations (gains/losses) spanning almost all the chromosomes, 3,512 dysregulated genes and 189 differentially expressed miRNAs. Moreover, bioinformatic analyses selected 196 genes and 46 anticorrelated miRNAs involved in carcinogenesis and stemness [14]. Remarkably, the abnormalities evidenced in 3AB-OS cells appear to be strongly congruent with abnormalities described in a large number of pediatric and adult OS patients, where karyotype ranging from haploid to near hexaploid with chromosome number ranging from 15 to 120 were described; in addition, a great number of chromosomal regions with structural abnormalities among which 17p11.2-13 that contains TP53 gene were found [15-17].

It is known that TP53 mutations occur in almost every type of cancer and often mutant p53 proteins (mutp53) express gain of function (GOF), which can enhance the ability of cancer cells to invade and metastasize, confer resistance to chemotherapies, promote genomic instability and drive multinucleation [18-27]. Recently, evidence linking p53 loss to stem-like phenotype in cancer has been reported [28]; however, how p53 contributes to acquisition of "stemness" at the molecular level and whether stem-like cells confer survival advantages to propagate the tumor remains to be resolved. Here, we investigated TP53 gene status and role in $3 \mathrm{AB}-\mathrm{OS}$ cells. We demonstrated that in $3 \mathrm{AB}-\mathrm{OS}$ cells, p53 is mutated (p53-R248W/P72R) and displays GOF activity. Furthermore, we showed that the ectopic expression of p53-R248W/P72R promoted cancer stem-like properties in osteosarcoma MG63 parental cells. The results suggest $\mathrm{p} 53-\mathrm{R} 248 \mathrm{~W} / \mathrm{P} 72 \mathrm{R}$ as a key regulator at the origin of the aggressiveness, chemoresistance and stemness of human $3 \mathrm{AB}-\mathrm{OS}$ CSCs.

\section{Materials and methods}

\section{Cell cultures}

Human osteosarcoma MG63 cells were acquired from Interlab Cell Line Collection (ICLC, Genova, Italy). The human 3AB-OS cancer stem cells have been produced in our laboratory [11] and patented (Pluripotent cancer stem cells: their preparation and use. Renza Vento and Riccardo Di Fiore, Patent Appln. No. FI2008A000238, December 11, 2008). Cell lines were cultured as monolayers in T-75 flask in Dulbecco's modified Eagle medium (DMEM), supplemented with $10 \%(\mathrm{v} / \mathrm{v})$ heat-inactivated fetal bovine serum (FBS), $2 \mathrm{mM} \mathrm{L}$-glutamine, $100 \mathrm{U} / \mathrm{ml}$ penicillin and $50 \mu \mathrm{g} / \mathrm{ml}$ streptomycin (Euroclone, Pero, Italy) in a humidified atmosphere of $5 \% \mathrm{CO}_{2}$ in air at $37{ }^{\circ} \mathrm{C}$. When cells grew to approximately $80 \%$ confluence, they were subcultured or harvested using $0.025 \%$ trypsinEDTA (Life Technologies Ltd, Monza, Italy).

\section{Morphological observation}

Cell morphology was evaluated using a Leica DM IRB inverted microscope (Leica Microsystems Srl, Milano, Italy). Images were photographed and captured by a computer-imaging system (Leica DC300F camera and Adobe Photoshop for image analysis).

\section{RT-PCR analysis for $p 53$}

RNA was isolated using RNeasy mini kit (Qiagen, Milano, Italy). cDNA was amplified from $1 \mu \mathrm{g}$ of RNA as previously reported [29] followed by polymerase chain reaction (PCR). The reactions omitting reverse transcriptase enzyme served as negative control. GAPDH was used as a housekeeping gene to demonstrate equal loading of RNA.
The amplified products were resolved by agarose gel electrophoresis ( $1 \%$ agarose, $0.5 \mu \mathrm{g} / \mathrm{ml}$ ethidium bromide; Sigma-Aldrich), and the bands were visualized and photographed with Chemi Doc XRS (BioRad Laboratories Srl, Segrate (MI), Italy). The primer sequences (Proligo USA, Milan, Italy) are as follows: TP53 (432 bp), forward 5'-GGGACAGC CAAGTCTGTG-3' and reverse 5'-GGAGTCTTCCAGTGTGAT-3'; GAPDH (200 bp), forward 5'-TGACATCAAGAAGGTGA- $3^{\prime}$ and reverse $5^{\prime}$-TCCA CCACCCTGTTGCTGTA-3'. For PCR analysis, the following protocol was performed: $95{ }^{\circ} \mathrm{C}$ for $5 \mathrm{~min}, 30$ cycles at $95{ }^{\circ} \mathrm{C}$ for $1 \mathrm{~min}, 54{ }^{\circ} \mathrm{C}$ for $1 \mathrm{~min}, 72{ }^{\circ} \mathrm{C}$ for $1 \mathrm{~min}$ and a final extension at $72{ }^{\circ} \mathrm{C}$ for $10 \mathrm{~min}$.

\section{Cell genomic DNA extraction, sodium bisulfite genomic treatment and TP53 methylation-specific PCR (MS-PCR)}

Genomic DNA was extracted from cultured cells using QIAamp DNA Mini Kit (Qiagen) following the manufacturer's instructions. Genomic DNA was bisulfite treated using an EpiTect Bisulfite Kit (Qiagen). The treatment of genomic DNA with sodium bisulfite converts unmethylated, but not methylated cytosines, into uracil, producing sequence differences between methylated and unmethylated DNA. Two micrograms of DNA were modified in $40 \mu \mathrm{l}$ of water with sodium bisulfite following the manufacturer's instructions. After bisulfite modification, PCR on the CpG island of the TP53 promoter was performed with the unmethylation-specific primers $(U)$ : 5'-TTAGTATTTA TGGTATTAGGTTGGT-3' and 5'-AACAAATAATCCACCTACCAA-3' ${ }^{\prime}$, and methylation-specific primers (M): 5'-GTATTTACGGTATTAGGTCGGC-3' and 5'-AAATAATCCGCCTACCGA-3', using 5U of AmpliTaq polymerase (Applied Biosystems, Foster City, CA) and the following PCR conditions: $95{ }^{\circ} \mathrm{C}$ for $5 \mathrm{~min}, 35 \mathrm{cycles}$ of $95{ }^{\circ} \mathrm{C}$ for $30 \mathrm{~s}, 51{ }^{\circ} \mathrm{C}$ for $45 \mathrm{~s}$ and $72{ }^{\circ} \mathrm{C}$ for $60 \mathrm{~s}$ and a final $8 \mathrm{~min}$ at $72{ }^{\circ} \mathrm{C}$. A methylated and bisulfite converted human control DNA (EpiTect PCR control DNA; Qiagen) was used as a positive control. Each PCR product was analyzed by electrophoresis on $2 \%$ agarose gel. Gel images were visualized and photographed with Chemi Doc XRS (Bio-Rad Laboratories Srl, Segrate (MI), Italy).

\section{TP53 fluorescent in situ hybridization (FISH) analysis}

FISH analyses were performed on MG63 and 3AB-OS cells by Toma Advanced Biomedical Assays S.p.A. (Busto Arsizio (VA), Italy) with p53 (17p13)/SE 17 probe (Kreatech Diagnostics, Amsterdam, The Netherlands), containing the p53 tumor suppressor gene-specific region and the chromosome 17 Satellite control probe. These analyses were performed following the manufacturer's protocol and analyzing 50 nuclei and 10 metaphases ( $1000 \times$ magnification).

\section{DNA sequence analysis of p53 exons 1-11}

DNA sequence analyses were performed on MG63 and 3AB-OS cells by BioRep S.r.l. (Milano, Italy). Genomic DNA was extracted from cultured cells using QIAamp DNA Mini Kit (Qiagen) following the manufacturer's instructions. PCR reactions were carried out under standard conditions with primer sets specific for the coding exons 1-11 of the TP53 gene reported in Supplementary Table 1. PCR products were purified using ExoSAP (Amersham Biosciences Italia, Milano, Italy) treatment and sequenced with the DYE-namic ET Dye Terminator Cycle Sequencing Kit (Amersham Biosciences Italia). Sequencing reactions were purified using the Montage SEQ96 Cleanup Kit (Millipore S.p.a., Milano, Italy), and sequencing runs were performed on the MegaBACE 500 DNA Analysis System (Amersham Biosciences Italia).

\section{Immunofluorescence Staining for p53}

The cells were fixed with 3.7\% formaldehyde for $10 \mathrm{~min}$ at room temperature and permeabilized with $0.1 \%$ Triton ${ }^{\circledR}$ X-100 (all from Sigma) in phosphate-buffered saline (PBS) for $5 \mathrm{~min}$. After washing with PBS, cells were incubated with anti-p53 primary antibody (diluted 
$1: 100$ in PBS $+1 \% \mathrm{BSA}+0.05 \% \mathrm{NaN}_{3}$; Santa Cruz Biotechnology, Santa Cruz, CA, USA) at $4{ }^{\circ} \mathrm{C}$, overnight. Cells were washed three times with PBS and incubated for $1 \mathrm{~h}$ at room temperature with Cy3or Cy2-conjugated secondary antibody (diluted 1:100 in PBS $+1 \%$ $\mathrm{BSA}+0.05 \% \mathrm{NaN}_{3}$; Jackson ImmunoResearch Laboratories, West Grove, PA, USA). Nuclei were counterstained with $2.5 \mu \mathrm{g} / \mathrm{ml}$ Hoechst 33342 (Sigma-Aldrich) for $10 \mathrm{~min}$. After three washes, cells were examined on a Leica DM IRB inverted microscope equipped with fluorescence optics and suitable filters for DAPI, FITC and rhodamine detection; images were photographed and captured by a computer-imaging system (Leica DC300F camera and Adobe Photoshop for image analysis).

Transient down-regulation of p53 by short interfering RNA (siRNA)

Cells were plated in a six-well plate format and cultured in DMEM medium, supplemented with $10 \%$ FBS, for 24 h to reach approximately $60-80 \%$ confluence. Specific siRNAs directed against p53, obtained by St Cruz Biotechnology as a pool of double-stranded RNA oligonucleotides, were transfected for $5 \mathrm{~h}$ into the cells at a final concentration of $50 \mathrm{nM}$, in the presence of $5 \mu \mathrm{l}$ Metafectene Pro (Biontex, Martinsried/ Planegg, GmBH, Munich, Germany) in a final volume of $1 \mathrm{ml}$ serumfree DMEM. At the end, the reaction was stopped replacing the culture medium with DMEM $+10 \%$ FBS. Cells were examined for p53 downregulation and other properties 24-72 h after transfection. siRNA, consisting in a scramble sequence, was used as a negative control.

\section{Growth curve and cell viability assays}

Total cell number and viability were evaluated by Trypan blue exclusion counting. Briefly, cells were harvested every $24 \mathrm{~h}$ and resuspended in PBS. Aliquots of cell suspensions were diluted with $0.4 \%$ trypan blue (Sigma-Aldrich Srl, Milano, Italy), pipetted onto a hemocytometer and counted under a microscope at $100 \times$ magnification. Live cells excluded the dye, whereas dead cells admitted the dye intensely staining with trypan blue. The number of viable cells for each experimental condition was counted and represented on a linear graph. Doubling time (DT) was estimated by the following equation: DT $=\left(t_{2}-t_{1}\right) \ln 2 / \ln X_{2} / X_{1}$, where $X_{2}$ and $X_{1}$ are the number of cells at $t_{2}$ and $t_{1}$.

\section{EdU in corporation assay}

For EdU (5-ethynyl-2'-deoxyuridine) incorporation experiments, cells were incubated with $10 \mu \mathrm{M}$ EdU (Click-iT ${ }^{\mathrm{TM}}$ EdU Alexa Fluor High-Throughput Imaging Assay, Invitrogen, Life Technologies Ltd, Monza, Italy) for $2 \mathrm{~h}$. Cells were then washed with PBS, fixed with $3.7 \%$ formaldehyde for $15 \mathrm{~min}$ at room temperature and permeabilized with $0.5 \%$ Triton X-100 (all from Sigma) in PBS for 20 min. After extensive washing with $3 \%$ bovine serum albumin (BSA) in PBS, incorporated EdU was detected by fluorescent-azide coupling reaction (Click-iT, Invitrogen). Briefly, cells were incubated for $30 \mathrm{~min}$ with azideconjugated Alexa Fluor 488 dye in TBS supplemented with $4 \mathrm{mM}$ $\mathrm{CuSO}_{4}$. Cells were then washed three times with $3 \%$ BSA in PBS. Nuclei were counterstained with $2.5 \mu \mathrm{g} / \mathrm{ml}$ Hoechst 33342 (Sigma-Aldrich), for $10 \mathrm{~min}$. After three washes, cells were examined by fluorescence microscopy using filters for DAPI and FITC. The percentage of EdU-positive nuclei was determined by counting five random high-powered fields $(400 \times)$.

\section{Cell death assays}

Apoptotic morphology was studied in cells stained with Hoechst 33342 (Sigma-Aldrich). In particular, cells were stained with Hoechst $33342(2.5 \mu \mathrm{g} / \mathrm{ml}$ medium $)$ for $30 \mathrm{~min}$ at $37{ }^{\circ} \mathrm{C}$, visualized by fluorescence microscopy using an appropriate filter for DAPI; images were photographed and captured. Cells were evaluated on the basis of their nuclear morphology, noting the presence of homogeneous chromatin, condensed chromatin, and fragmented nuclei.

Apoptosis was also studied by flow cytometry of either DNA content or annexin V labelling. For DNA staining, trypsinized cell suspensions were centrifuged, washed 3 times with PBS and resuspended at $1 \times$ $10^{6}$ cells $/ \mathrm{ml}$ in PBS. Cells were mixed with cold absolute ethanol and stored for $1 \mathrm{~h}$ at $4{ }^{\circ} \mathrm{C}$. After centrifugation, cells were rinsed 3 times in PBS, and the pellet was suspended in $1 \mathrm{ml}$ of propidium iodide (PI) staining solution ( $3.8 \mathrm{mM}$ sodium citrate, $25 \mu \mathrm{g} / \mathrm{ml} \mathrm{PI,} 10 \mu \mathrm{g} / \mathrm{ml}$ RNase A; Sigma-Aldrich Srl, Milano, Italy) and kept in the dark at $4{ }^{\circ} \mathrm{C}$ for $3 \mathrm{~h}$ prior to flow cytometry analysis. The proportion of cells giving fluorescence in the sub-G0/G1 peak of cell cycle was taken as a measure of apoptosis.

For annexin V labelling, trypsinized cell suspensions were centrifuged, washed 3 times with PBS and resuspended in $1 \times$ annexin $\mathrm{V}$ binding buffer (BD Biosciences Pharmingen, San Diego, CA) at a concentration of $1 \times 10^{6}$ cells $/ \mathrm{ml}$. One hundred microliters of cell suspension was then incubated with $5 \mu \mathrm{L}$ of annexin V-FITC (BD Biosciences) and $5 \mu \mathrm{L}$ of PI for $15 \mathrm{~min}$ at a room temperature in the dark. Double labeled with annexin $\mathrm{V}$ and PI allows a distinction of early apoptotic (annexin $\mathrm{V}^{+} / \mathrm{PI}^{-}$) and late apoptotic/necrotic (annexin $\mathrm{V}^{+} / \mathrm{PI}^{+}$) cells. Flow cytometry analyses were performed by a COULTER EPICS XL flow cytometer (Beckman Coulter Srl, Cassina De Pecchi (MI), Italy) equipped with a single Argon ion laser (emission wavelength of $488 \mathrm{~nm}$ ) and Expo 32 software. The green fluorescence was measured in the FL1 channel using a 515-nm BP filter, and the red fluorescence was measured in the FL3 channel using a 620 -nm BP filter. At least $1 \times 10^{4}$ cells per sample were analyzed and data were stored in list mode files.

\section{Measurement of mitochondrial transmembrane potential ( $\Delta \psi m)$}

Mitochondrial membrane potential was measured by the cationic lipophilic fluorochrome 3,3-dihexyloxacarbocyanine (DiOC6 Molecular Probes, Eugene, OR), which exclusively emits within the spectrum of green light. Loss in DiOC6 staining indicates disruption of the mitochondrial inner transmembrane potential $(\Delta \Psi \mathrm{m})$. Cells were incubated with $40 \mathrm{nM}$ DiOC6 for $20 \mathrm{~min}$ at $37^{\circ} \mathrm{C}$, washed twice with PBS and analysed by flow cytometry. The green fluorescence was measured as above described.

\section{In vitro matrigel invasion assay}

Invasion assays were performed using 6-well invasion chamber system (BD Biosciences, Discovery Labware, Becton Dickinson, Buccinasco, Italy). Cells were trypsinized and counted with a hemocytometer using trypan blue, and viable cells were seeded in the upper chamber at $1 \times$ $10^{5}$ cells/well in serum-free DMEM. DMEM supplemented with $10 \%$ FBS (used as a chemoattractant) was placed in the bottom well. Incubation was carried out for $48 \mathrm{~h}$ at $37{ }^{\circ} \mathrm{C}$ in humidified air with $5 \% \mathrm{CO}_{2}$. Nonmigratory cells in the upper chamber were then removed with a cotton-tip applicator. Migrated cells on the lower surface were stained with Hoechst 33342 (2.5 $\mu \mathrm{g} / \mathrm{ml}$; Sigma-Aldrich) for $10 \mathrm{~min}$ and then visualized under an inverted microscope. The number of migrating cells was determined by counting five high-powered fields $(200 \times)$ on each membrane. Four independent experiments were performed in triplicate.

\section{Construction of expression vector expressing p53 mutation $(p 53-R 248 W / P 72 R)$ and stable transfection}

RNA from 3AB-OS cell line was isolated using TRI Reagent (SigmaAldrich), according to manufacturer's instructions. cDNA was amplified from $2 \mu \mathrm{g}$ of RNA using M-MuLV reverse transcriptase (New England Biolabs, Euroclone, Pero, Italy). The following protocol was performed: RNA was incubated with dNTPs (Amersham Biosciences) and Random Examers (Promega Italia Srl, Milano, Italy) at $70{ }^{\circ} \mathrm{C}$ for $10 \mathrm{~min}$ and in 
ice for $1 \mathrm{~min}$; then, after the addition of M-MuLV and the specific buffer, the incubation was performed at $42{ }^{\circ} \mathrm{C}$ for $1 \mathrm{~h}$ and at $90{ }^{\circ} \mathrm{C}$ for $10 \mathrm{~min}$. The following primers were used to amplified TP53 $(\approx 1.2 \mathrm{~kb})$ : forward (BamHI restriction site-containing) 5'-CGTAGGATCCAGCCATGGAGGA GCCGCAG-3' and reverse (Xhol restriction site-containig) 5'-CGGATC TCGAGCAATTCAGTCTGAGTCAGGCC-3'. For PCR amplification with Phusion Taq polymerase (New England Biolabs), the following protocol was performed: $98{ }^{\circ} \mathrm{C}$ for 2 min; 12 cycles at $98{ }^{\circ} \mathrm{C}$ for $10 \mathrm{~s}, 63{ }^{\circ} \mathrm{C}$ for $20 \mathrm{~s}$ and $72{ }^{\circ} \mathrm{C}$ for $30 \mathrm{~s} ; 18$ cycles at $98{ }^{\circ} \mathrm{C}$ for $10 \mathrm{~s}$ and $72{ }^{\circ} \mathrm{C}$ for $30 \mathrm{~s}$; a final extension at $72{ }^{\circ} \mathrm{C}$ for $7 \mathrm{~min}$. The amplified product was resolved by agarose gel electrophoresis ( $1 \%$ agarose and $0.5 \mu \mathrm{g} / \mathrm{ml}$ ethidium bromide; Sigma-Aldrich) and the band was extracted using Wizard SV Gel and PCR Clean-up system (Promega Italia Srl). PCR product and pcDNA 3.1 vector (Invitrogen) were digested for $2 \mathrm{~h}$ at $37{ }^{\circ} \mathrm{C}$ with BamHI-HF and XhoI (New England Biolabs), resolved by agarose gel electrophoresis and extracted. Vector dephosphorylation and ligation reactions were performed using the Rapid Dephosphorylation and Ligation kit (Roche, Milano, Italy) according to manufacturer's instructions. The ligation mixture was transformed into calcium chloride-competent DH5 $\alpha$ cells (Invitrogen). Plasmids after BamHI-Xhol digestion that showed the presence of a 1.2-kb insert were validated by sequencing (Ceinge Sequencing Service, Ceinge, Napoli, Italy).

MG63 cells were plated in 6-well dishes until they reached 90\% confluence and then transfected with p53-R248W/P72R-pcDNA 3.1 or empty vector, as a control, using Lipofectamine 2000 (Invitrogen) according to manufacturer's instructions. Two days after transfections, the cells were transferred in $100 \mathrm{~mm}$ dishes in selective medium con-

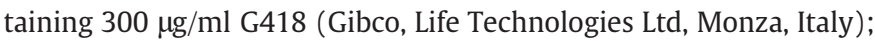
the medium was replaced every 3-4 days. A plate of untrasfected cells was used as a control for the selection.

\section{Sarcosphere formation assay}

MG63 cells transfected with pcDNA3.1-p53-R248W/P72R or empty pcDNA3.1 vector were seeded in 6-well ultra-low attachment plates (Corning Costar, Euroclone) at a density of 500 cells/well with $3 \mathrm{ml}$ stem cell medium consisting of DMEM/F12 (Gibco), B27 ( $1 \times$ Gibco), recombinant human epidermal growth factor (rhEGF, $20 \mathrm{ng} / \mathrm{ml}$; SigmaAldrich) and basic fibroblast growth factor (bFGF, $20 \mathrm{ng} / \mathrm{ml}$; SigmaAldrich). The stem cell medium was changed every 3 days, and cells were observed every day by microscopy. After the primary spheres reached approximately $\geq 50 \mu \mathrm{m}$ in diameter (determined using the Image software), they were collected by gentle centrifugation (800 rpm), enzymatically dissociated $\left(10 \mathrm{~min}\right.$ at $37{ }^{\circ} \mathrm{C}$ in $0.05 \%$ trypsin-EDTA; Life Technologies Ltd) to single cells and replanted into 6-well ultra-low attachment plates with 500 cells/well and cultured with stem cell medium to generate spheres of the next generation.

\section{Colony formation assay}

MG63 cells transfected with pcDNA3.1-p53-R248W/P72R or empty pcDNA3.1 vector were seeded in 6-well plates at a density of 100 cells/well with $3 \mathrm{ml}$ culture medium and incubated for 10 days. The medium was changed every 3 days, and cells were observed every day by microscopy. On the tenth day, media was removed from the wells and washed once with ice-cold PBS. The colonies were fixed with $50 \%$ EtOH and stained with $1 \%$ methylene blue (Sigma-Aldrich) for $10 \mathrm{~min}$. After three washes with PBS, the colonies consisting of $>50$ cells were counted using microscopy. Colony size was determined by measuring the area with the ImageJ software.

\section{Scratch/wound-healing assay}

To analyze cell migration by wound healing, confluent monolayers of MG63 cells transfected with pcDNA3.1-p53-R248W/P72R or empty pcDNA3.1 vector and cultured in 6-well plates were scratched with a $200-\mu$ pipette tip to generate the wound. One hour before scratching, the medium was replaced with medium containing $0.1 \%$ FBS to minimize the cell proliferation. Phase-contrast photographs of the same region were taken with the same magnification $(100 \times)$ at 0,8 and $24 \mathrm{~h}$ post-wounding. The extent of wound closure was determined by measuring with the ImageJ software the area of cells that migrated into the wound and then dividing by the total area of wound.

\section{Flow cytometry analysis of CD133, ABCG2 and p53 expression}

Cells were detached using $0.025 \%$ trypsin-EDTA in PBS, counted and washed in $0.1 \% \mathrm{BSA}$ in PBS at $4{ }^{\circ} \mathrm{C}$. At least 500,000 cells (in $100 \mu \mathrm{l} \mathrm{PBS/}$ $0.5 \% \mathrm{BSA}$ ) were incubated with fluorescent-labelled monoclonal antibodies or respective isotype controls $\left(1 / 10\right.$ diluted $4{ }^{\circ} \mathrm{C}$ for $30 \mathrm{~min}$ in the dark). After washing steps, the labelled cells were analyzed by flow cytometry using COULTER EPICS XL (Beckman-Coulter Srl) and Expo 32 software. The antibodies used were mouse anti-human CD133/2 PE conjugated (Miltenyi Biotec S.r.l., Bologna, Italy), mouse anti-human ABCG2 nonconjugated (Santa Cruz Biotechnology) and mouse anti-human p53 nonconjugated (Santa Cruz Biotechnology). For indirect labelling, cells were incubated with a compatible secondary antibody FITC conjugated (Santa Cruz Biotechnology, Inc.). For intracellular staining of CD133, ABCG2 and p53, cells were processed using the Caltag Fix \& Perm Kit (Invitrogen) following the manufacturer's guidelines. The green fluorescence was measured as described in the Cell death assays section, and the phycoerythrin fluorescence was measured in the FL2 channel using a 575-nm BP filter. At least $1 \times 10^{4}$ cells per sample were analyzed, and data were stored in list mode files. The expression of cell markers was determined by comparison with isotype control.

\section{Cell cycle and proliferation analyses}

Cell cycle phase distribution was studied by flow cytometry of DNA content. This method was described in the Cell death assays section. The proliferation index was calculated as the sum of cells in S and G2/M phases of cell cycle [30].

\section{RNA extraction and real-time RT-PCR}

RNA was extracted by Trizol reagent (Life Technologies Ltd, Monza, Italy); a DNase I treatment step was included. One microgram of total RNA was reverse transcribed in a final volume of $20 \mu \mathrm{l}$ reverse transcription (RT) by using a Super-Script First-Strand Synthesis kit for RT-PCR (Life Technologies Ltd) according to the manufacturer's instructions. The resulting cDNAs were used for quantitative analysis by real-time PCR (qPCR) using the primers (Proligo, Milan, Italy) reported in Supplementary Table 2 and the Power SYBR Green PCR Master Mix (Applied Biosystem, Warrington, UK). Reactions were performed in 48-well plates according to manufacturer's instructions, using Applied Biosystems StepOneTM instrument. Each reaction mixture contained $2 \mu \mathrm{l}$ of template cDNA, $12.5 \mu \mathrm{l}$ of SYBR Green PCR Master Mix 2X, a final concentration of $300 \mathrm{nM}$ of forward and reverse primers and RNase-free $\mathrm{dH}_{2} \mathrm{O}$ to a final volume of $25 \mu \mathrm{l}$. qPCRs were performed in triplicate and repeated for confirmation. PCR cycling was performed as follows: $95{ }^{\circ} \mathrm{C}$ for $10 \mathrm{~min}, 95^{\circ} \mathrm{C}$ for $30 \mathrm{~s}, 60^{\circ} \mathrm{C}$ for $60 \mathrm{~s}, 72{ }^{\circ} \mathrm{C}$ for $30 \mathrm{~s}$ for 40 cycles and a final extension at $72{ }^{\circ} \mathrm{C}$ for $5 \mathrm{~min}$. To determine primer specificity, three stages $\left(95{ }^{\circ} \mathrm{C}\right.$ for $15 \mathrm{~s}, 60{ }^{\circ} \mathrm{C}$ for $20 \mathrm{~s}$ and $95{ }^{\circ} \mathrm{C}$ for $15 \mathrm{~s}$, with a ramping time of $20 \mathrm{~min}$ ) were added at the end of the PCR to obtain dissociation curves for each gene. To verify that the RT-PCR signals derived from RNA rather than genomic DNA, for each gene tested a control identical to the test assay but omitting the RT reaction (no RT control) was included. qPCR data were analyzed by SDS 2.1 software. Relative transcript levels were determined using the $2^{-\Delta \Delta C t}$ method and normalized to endogenous $\beta$-actin control. 


\section{Western blot analysis}

Cells were washed in PBS and incubated on ice-cold lysis buffer (RIPA buffer $50 \mu \mathrm{l} / 10^{6}$ cells) containing protease inhibitor cocktail (Sigma-Aldrich) for $30 \mathrm{~min}$ and sonicated three times for $10 \mathrm{~s}$. Equivalent amounts of proteins $(40 \mu \mathrm{g})$ were separated by SDSpolyacrylamide gel electrophoresis and transferred to a nitrocellulose membrane (Bio-Rad) for detection with primary antibodies and the appropriate horseradish peroxidase-conjugated secondary antibodies. Immunoreactive signals were detected using enhanced chemiluminescence (ECL) reagents (Bio-Rad). The correct protein loading was confirmed by stripping the immunoblot and reprobing with primary antibody for actin (diluted 1:500; Sigma). Bands were visualized and photographed with Chemi Doc XRS (Bio-Rad). Quantification was performed using Quantity One software, and the data (relative density normalized to actin) were expressed as mean $\pm \mathrm{SD}$ of four experiments. The primary antibodies are provided in Supplementary Table 3.

\section{Statistical Analysis}

Data, represented as mean $\pm S D$, were analyzed using the 2-tailed Student $t$-test using Microsoft Excel. Differences were considered significant when $P<0.05$.

\section{Results}

p53 gene and protein status in MG63 and 3AB-OS cells

At first, we examined by RT-PCR analysis the expression of TP53 mRNA in both 3AB-OS and MG63 parental cells. We detected mRNA transcript for TP53 in 3AB-OS cells but not in MG63 cells (Fig. 1A). Because a low or unmeasurable level of TP53 gene expression may be correlated with promoter hypermethylation [31-34], we also evaluated the methylation status of the TP53 promoter by MSP in both cell lines. As it can be seen in Fig. 1B, in 3AB-OS cells, the promoter was found unmethylated, while MG63 cells showed an aberrant TP53 promoter methylation status.

To determine the chromosome 17 (chr17) and TP53 copy numbers, MG63 and 3AB-OS cells were hybridized using a dual-color direct labelled probe specific for chr17 $\alpha$-satellite and for TP53 gene region. We have analyzed interphase (INT) and metaphase (MET) nuclei showing (Fig. 1C) that both cell lines exhibit alterations of chr17 and TP53 gene; MG63 cells show chr17 trisomy and one TP53 signal which did not colocalize with chr17, whereas 3AB-OS cells show chr17 tetrasomy with three and four TP53 signals, some of which colocalizing with chr17.

We also sequenced the coding exons 1-11 of TP53 gene in both $3 \mathrm{AB}-$ OS and MG63 cells. As shown in Fig. 1D, 3AB-OS cells evidenced alterations in the exons 4 and 7. More precisely, codon 72 CCC was altered into CGC in the sequence orientation (p53Ex4s), and from GGG into
A

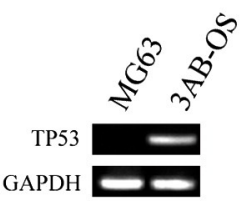

$\mathrm{D}$

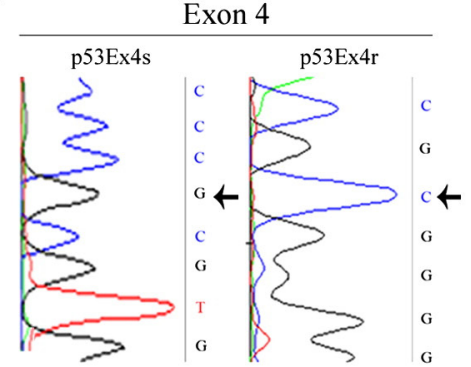

$\mathrm{CCC}$ to $\mathrm{CGC}$
B

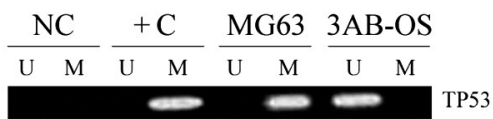

$\mathrm{C}$
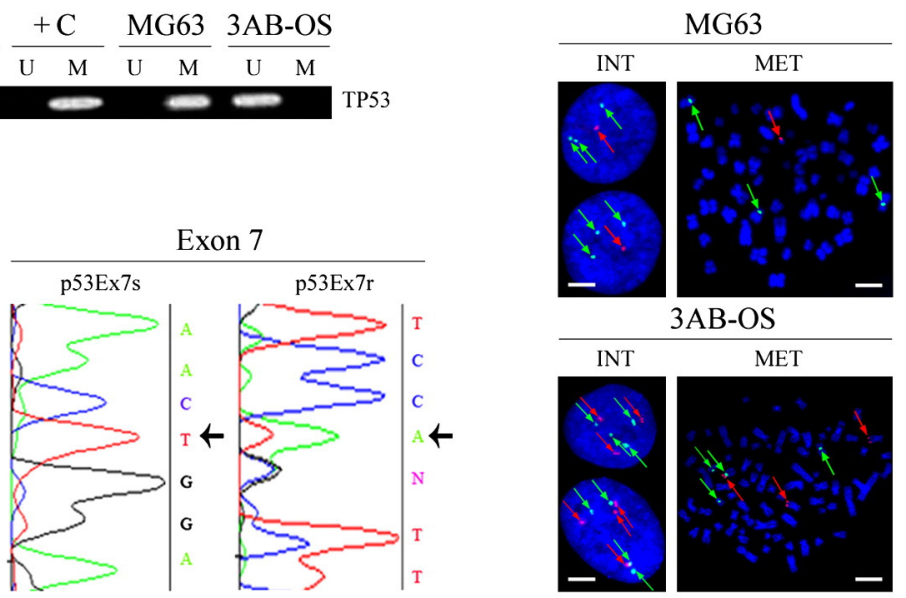

GCC to ACC

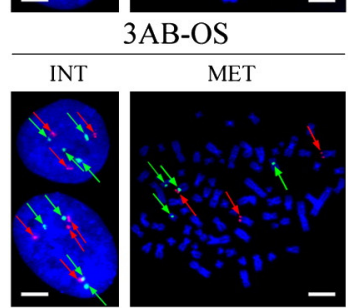

CGG to TGG

$\mathrm{F}$
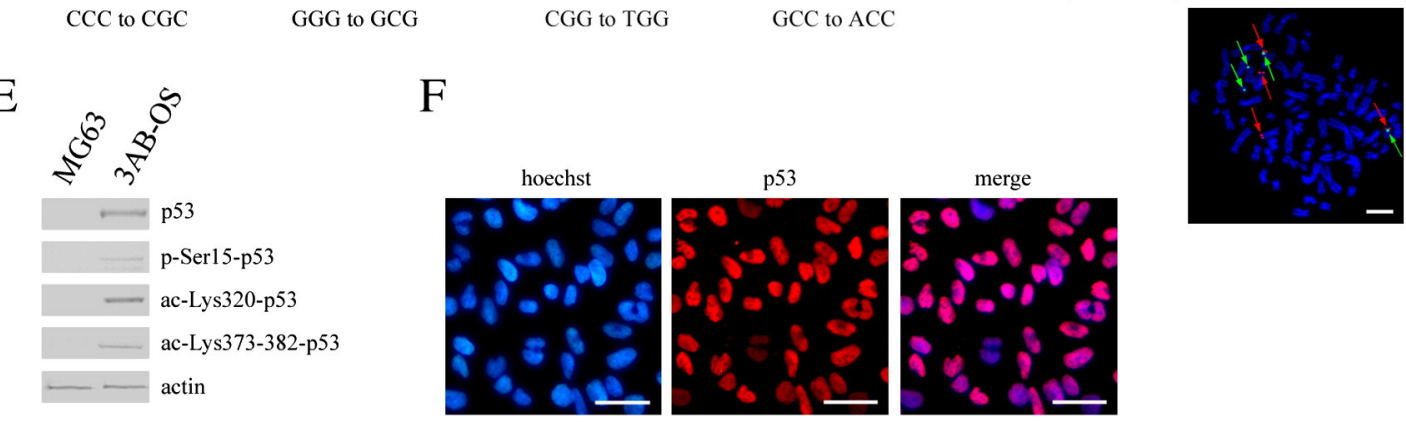

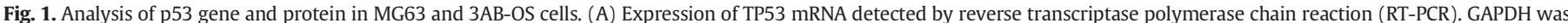

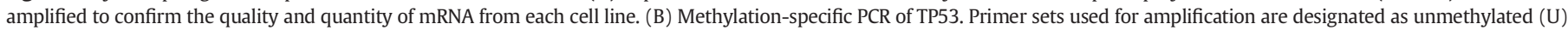

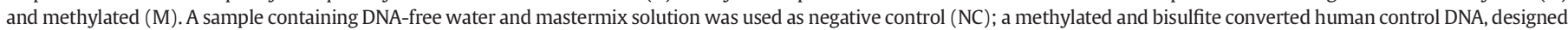

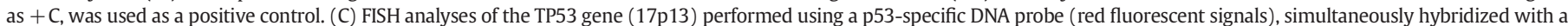

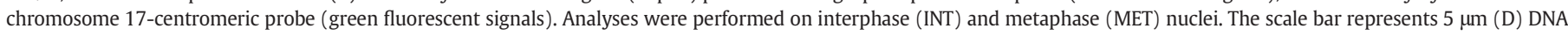

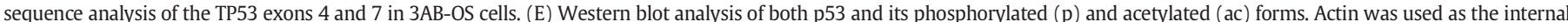

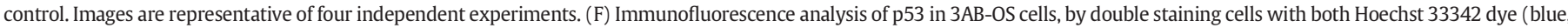

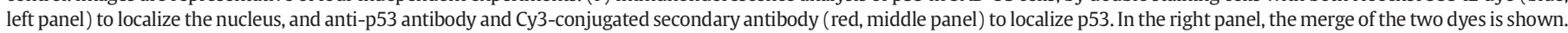
The scale bar represents $25 \mu \mathrm{m}$. Images are representative of four independent experiments. 
GCG on the reverse strand (p53Ex4r). This transversion produced an amino acid substitution of arginine for proline (P72R), a common polymorphism of TP53 gene. Fig. 1D also shows that codon 248 CGG was altered into TGG in the sequence orientation (p53Ex7s), and from GCC into ACC on the reverse strand ( $\mathrm{p} 53 \mathrm{Ex} 7 \mathrm{r}$ ). This transition produced an amino acid substitution of tryptophan for arginine (R248W) that affects p53 DNA binding ability. Since sequencing reactions of both strands confirmed the presence of only the altered nucleotide, we noticed that the mutations were indeed homozygously present in 3AB-OS cells. No alterations were detectable in the exons of MG63 cells (data not shown).

Given the results obtained above, we have examined the expression of mutp53 (p53-R248W/P72R) by western blot analysis. As shown in Fig. 1E, the protein was detected in $3 \mathrm{AB}-\mathrm{OS}$ cells while it was not found in MG63 cells. We have also analyzed the post-translational phosphorylation and acetylation status of the protein. As shown in Fig. 1E, the p53-R248W/P72R protein resulted phosphorylated at Ser15 and acetylated at Lys320 and Lys373-382; furthermore, immunofluorescence analysis (Fig. 1F) evidenced that in $3 \mathrm{AB}-\mathrm{OS}$ cells, it exhibited a nuclear localization. Overall, these results demonstrated that in $3 \mathrm{AB}-\mathrm{OS}$ cells, TP53 gene is mutated and that p53-R248W/P72R is stabilized and has nuclear localization.

\section{Study of gain of function of p53-R248W/P72R in 3AB-OS cells}

Aimed at evaluating whether, in 3AB-OS cells, p53-R248W/P72R has acquired GOF activities (enhanced cell proliferation, invasiveness and resistance to apoptosis), we have depleted the protein by smallinterfering RNA (siRNA). To this purpose, 3AB-OS cells were transfected with p53-siRNA or a scrambled siRNA (Scr-siRNA). Then, first, we checked the effects of the p53-targeting siRNA on the level of endogenous protein. At 24-72 h after transfection, the content of the protein was assessed by western blot (Fig. 2A) and immunofluorescence (Fig. 2B) analyses. Both the analyses showed that after 24-72 h of p53-siRNA transfection, p53-R248W/P72R level potently lowered. The effects were observed at $24 \mathrm{~h}$ after transfection and peaked at $48 \mathrm{~h}$ when more than $70 \%$ reduction in the content of the protein was observed. Thereafter, p53-R248W/P72R levels markedly went up, so that at $72 \mathrm{~h}$ after transfection, we only observed a $22 \%$ reduction in its level. This suggested that, at that time, the transient silencing was in rapid recovery. Overall, the results suggested that the optimal silencing efficiency was reached at $48 \mathrm{~h}$ after transfection. The knockdown of the protein was specific as no protein reduction was observed in cells transfected with Scr-siRNA.

\section{p53-R248W/P72R-knockdown inhibits 3AB-OS cell proliferation}

To evaluate whether p53-R248W/P72R-knockdown modified the growth of $3 \mathrm{AB}-\mathrm{OS}$ cells, untransfected cells and cells transfected with Scr-siRNA or with p53 siRNA were microscopically observed and analysed (0-72 h) for cell number, percentage of cells in the S-phase of cell cycle (EdU incorporation) and percentage of viability. In Fig. 3A, the image obtained by phase contrast microscopy shows that upon knockdown of p53-R248W/P72R, in comparison to untransfected or Scr-siRNA-transfected cells, cell number lowered. The results were in accordance with the trend of the p53-R248W/P72R protein level observed after p53siRNA transfection. Fig. 3B also shows that p53-R248W/ P72R depletion reduced the growth rate and the replication rate of 3ABOS cells, whereas it did not induce loss of cell viability. Also, the speed of cell growth and replication reflected the trend of p53-R248W/P72Rknockdown. There was no statistically significant difference between untransfected cells and cells transfected with Scr-siRNA. These results well agreed with microscopy analysis. Next, we examined the expression of a number of cell cycle-related proteins and genes at $48 \mathrm{~h}$ posttransfection. In Fig. 3C, western blot and real-time PCR analyses showed that the p53-R248W/P72R-knockdown markedly increased the levels of
pRb, p130, p107, E2F1, E2F4, GADD45, p21 and p27, whereas it potently decreased CDK4 levels. No alteration in the expression of cyclins and other CDKs was observed (data not shown).

\section{p53-R248W/P72R-knockdown reduces resistance to TRAIL-induced apoptosis and regulates $\mathrm{BCl}-2$ family members and mitochondrial membrane potential}

We have previously demonstrated that $3 \mathrm{AB}-\mathrm{OS}$ cells express low levels of the death receptors FAS and DR4 [14] and show strong resistance to TRAIL (TNF-related apoptosis inducing ligand) (effects evaluated using TRAIL concentrations up to $100 \mathrm{ng} / \mathrm{ml}$, unpublished data). Here, we evaluated whether the p53-R248W/P72R-knockdown modifies the expression levels of DR4 (TRAIL-R1), KILLER/DR5 (TRAIL-R2) and FAS/CD95 at $48 \mathrm{~h}$ post-transfection. In Fig. 4A, western blot analyses show that p53-R248W/P72R depletion significantly increased protein expression levels of DR4 and DR5, whereas it did not change FAS level. Thus, to evaluate TRAIL sensitivity, untransfected cells and cells transfected for $24 \mathrm{~h}$ with Scr-siRNA or p53-siRNA were treated with TRAIL (40 ng/ml) for $36 \mathrm{~h}$. In Fig. 4B, phase contrast microscopy shows that TRAIL markedly reduced cell number also inducing apoptosis in p53-silenced cells, as suggested by the presence of round-shaped cells floating in the medium, membrane blebbing and apoptotic body formation. As chromatin condensation and nuclear fragmentation remain the hallmarks of apoptotic cells, apoptosis was assessed by staining nucleic acid with Hoechst 33342. As shown Fig. 4B, in p53-siRNAtransfected cells, TRAIL induced typical apoptotic nuclei, exhibiting highly fluorescent condensed and fragmented chromatin. Apoptosis was also studied by flow cytometry of either DNA content or annexin V labelling. Fig. 4C shows that treatment with TRAIL resulted in 29\% of cells accumulation in sub-G0-G1 phase with a $20 \%$ of early apoptotic cells (annexin $\mathrm{V}^{+} / \mathrm{PI}^{-}$) in p53-siRNA-transfected cells. The effects of TRAIL were also evidenced in both untransfected and Scr-siRNAtransfected cells, but these effects were much less pronounced than in p53-siRNA-transfected cells. Collectively, these results demonstrate that p53-R248W/P72R-knockdown sensitizes 3AB-OS cells to TRAILinduced apoptosis. We also investigated by cytofluorimetric analysis if $\mathrm{p} 53-\mathrm{R} 248 \mathrm{~W} / \mathrm{P} 72 \mathrm{R}$ can attenuate mitochondrial apoptosis signalling pathways. $\mathrm{DiOC}_{6}$ staining revealed that the p53-R248W/P72Rknockdown induced a significant decrease in fluorochrome uptake, indicating a loss of $\Delta \psi \mathrm{m}$ (Fig. 4D). To further dissect the molecules involved in the mechanism, we investigated whether the p53-R248W/ P72R-knockdown modifies the expression levels of both anti-apoptotic (Bcl-2 and Bcl-XL) and pro-apoptotic (Bax and Puma) factors. In Figs. $4 \mathrm{E}$ and $4 \mathrm{~F}$, real-time PCR and western blot analyses showed that the p53-R248W/P72R-knockdown significantly decreased Bcl-2 and $\mathrm{Bcl}-\mathrm{XL}$ levels while it increased Bax and Puma levels. These results well agreed with those obtained by cytofluorimetric analysis.

\section{p53-R248W/P72R shows the gain-of-function properties involved in promotion of cell invasiveness}

To evaluate whether p53-R248W/P72R-knockdown influences 3ABOS cells invasiveness, we performed Matrigel invasion transwell assays. As shown in Fig. 5A, p53-siRNA transfection potently decreased (-80\%) the invasive capability of $3 \mathrm{AB}-\mathrm{OS}$ cells, whereas no statistically significant difference was observed in untransfected and Scr-siRNAtransfected cells. We also examined the expression of a number of cell invasion-related genes and proteins at $48 \mathrm{~h}$ post-transfection. In Figs. 5B and 5C, real-time PCR and western blot analyses showed that p53-R248W/P72R-knockdown significantly decreased the levels of the invasive proteins matrix metalloproteinases 2 and 9 (MMP2 and MMP9), integrin alfa5 (ITG $\alpha 5$ ) and integrin alfaV (ITG $\alpha \mathrm{V}$ ) while it increased the levels of the cell adhesion protein E-Cadherin, without altering the expression of proteins involved in mesenchymal phenotype ( $\mathrm{N}$-cadherin, $\beta$-catenin and vimentin). 
A

\begin{tabular}{|c|c|c|c|c|c|}
\hline time (h) & 24 & & 48 & & 72 \\
\hline Scr-siRNA & $-\quad+$ & & -+ & - & \\
\hline p53-siRNA & $-\quad-$ & + & $-\quad-$ & + & $-\quad-$ \\
\hline
\end{tabular}

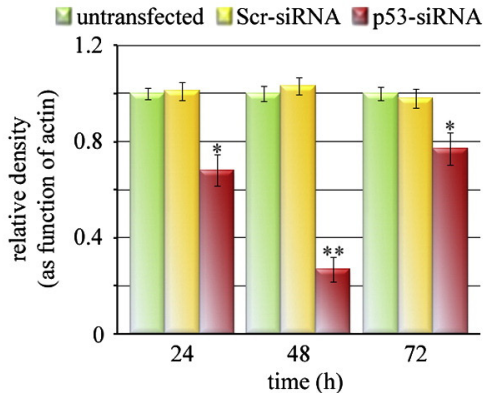

B

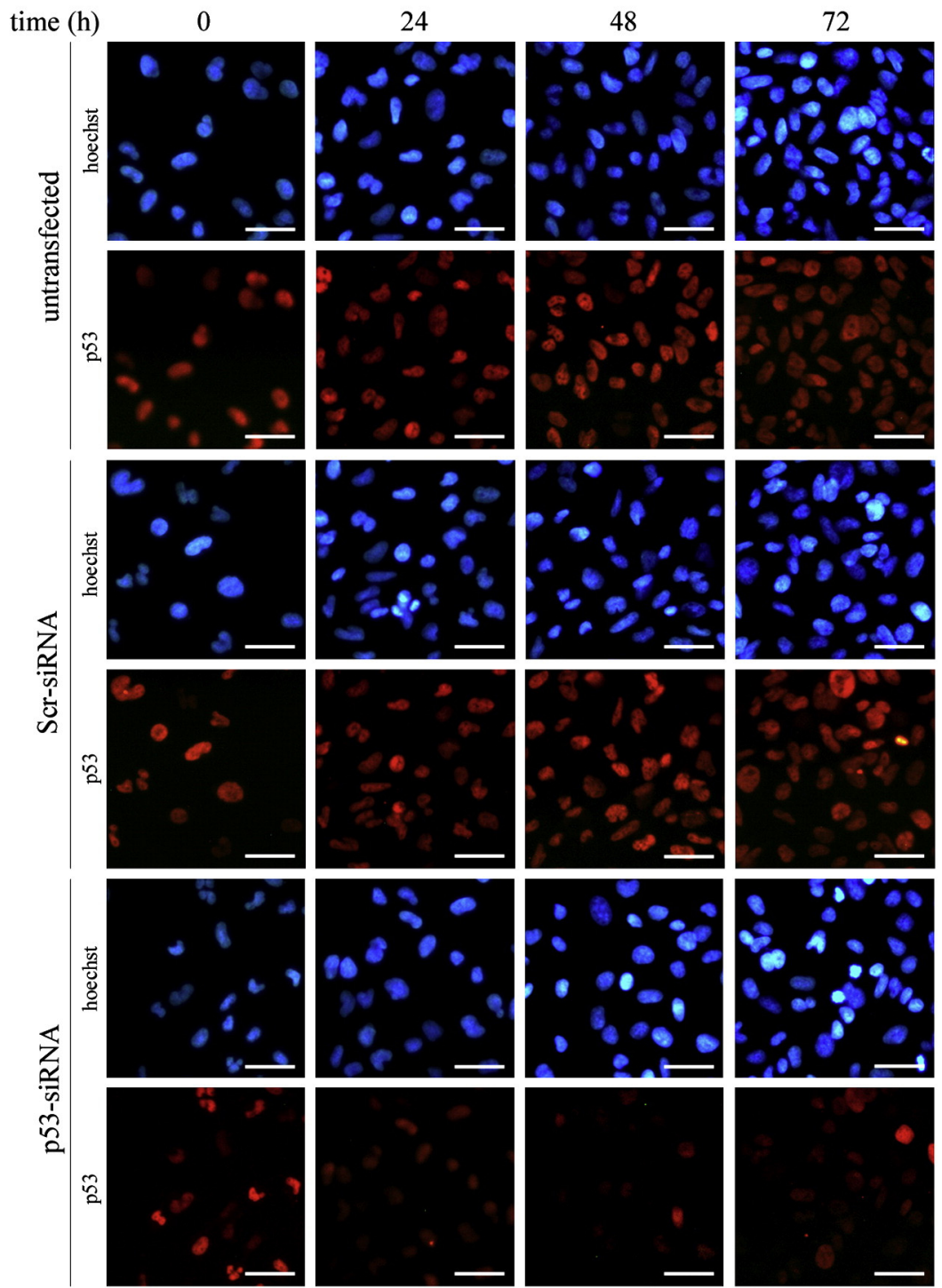

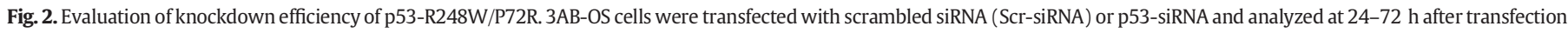

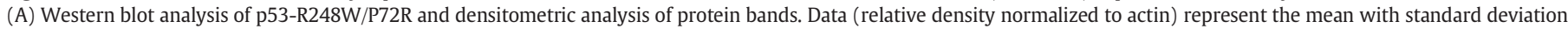

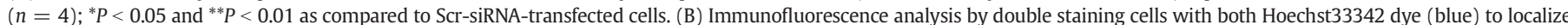

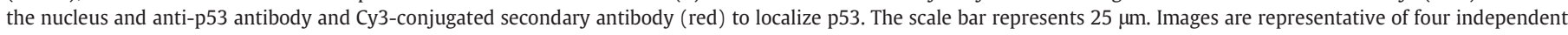
experiments. 
A

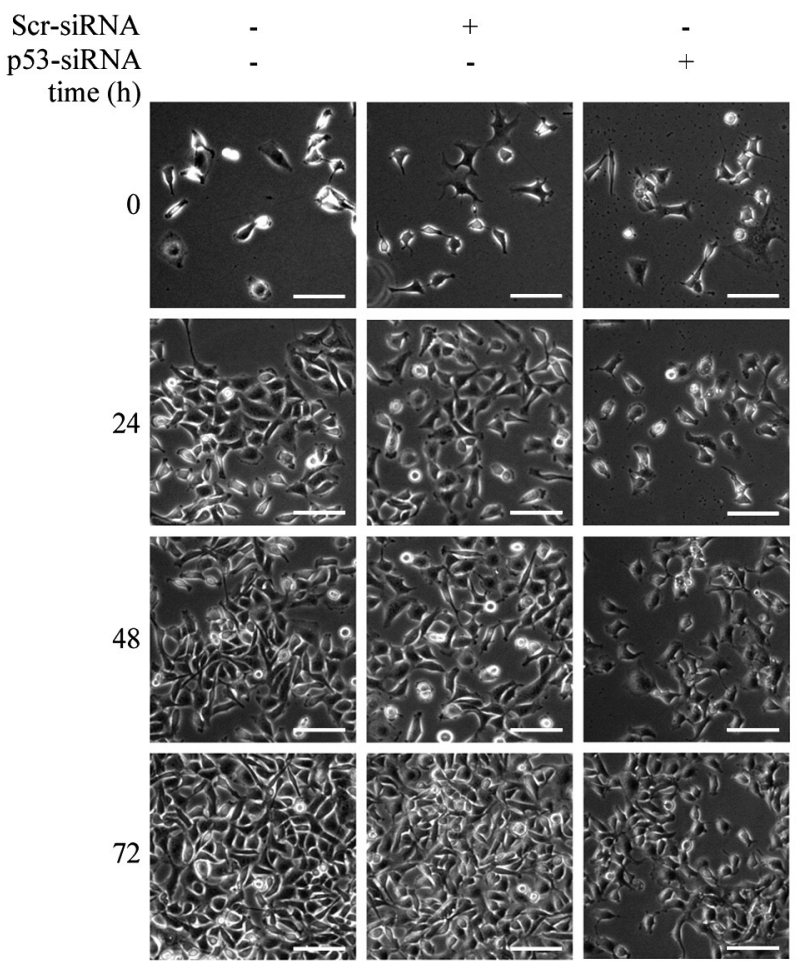

B (a)

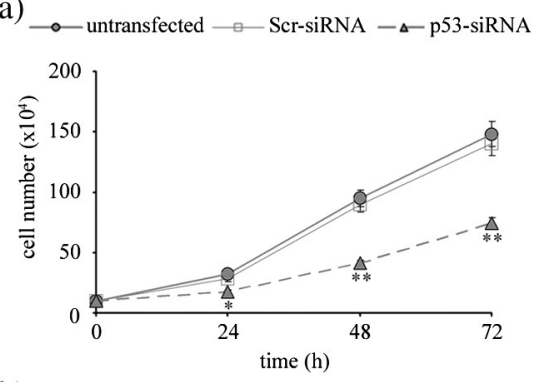

(b)

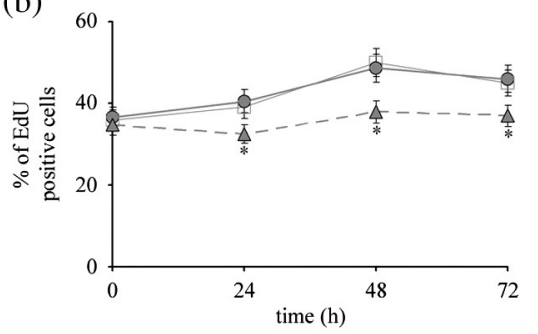

(c)

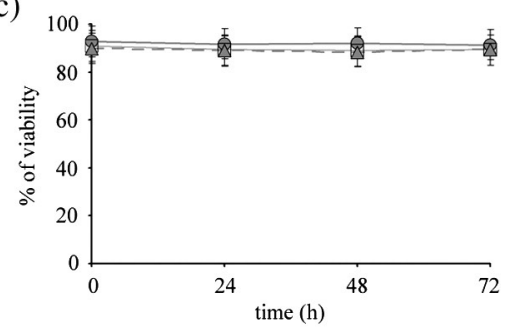

C (a)

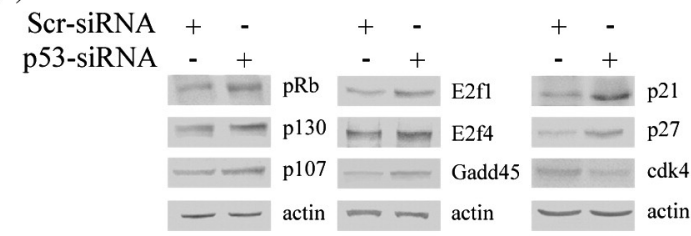

(b)

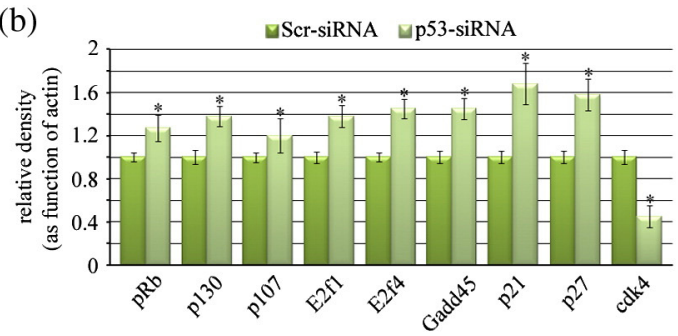

(c)

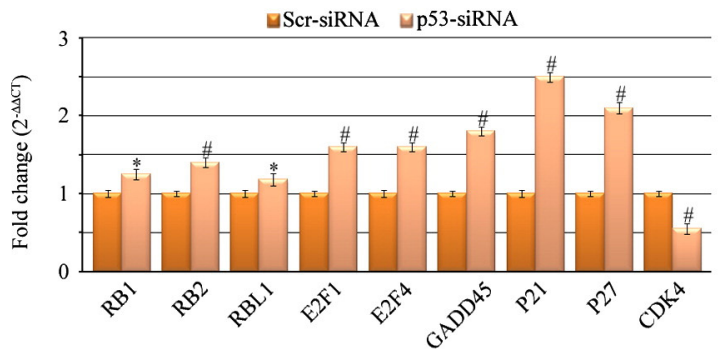

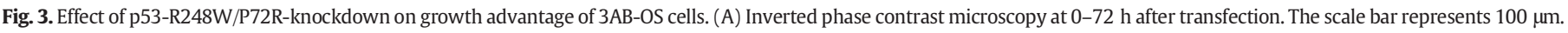

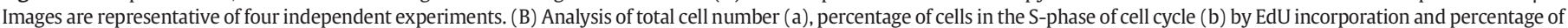

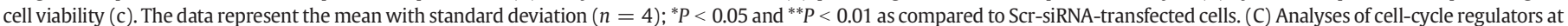

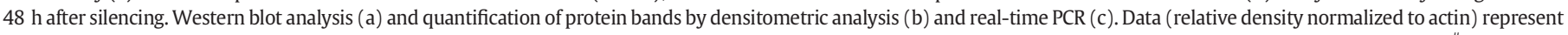

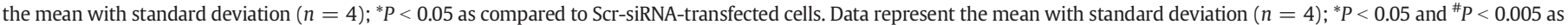
compared to Scr-siRNA-transfected cells.

\section{p53-R248W/P72R-knockdown affects the expression of stem-cell markers}

Previously, we have shown that $3 \mathrm{AB}-\mathrm{OS}$ cells express a large number of genes required for maintaining stemness [11] and that they morphologically and functionally transdifferentiate in vitro into cells of all three primary germ layers (ectoderm, endoderm and mesoderm) [12]. We also demonstrated that stemness markers were profoundly downregulated in differentiated cells. Here we have shown (Fig. 6A) that undifferentiated 3AB-OS cells strongly expressed p53-R248W/P72R while it profoundly lowered in derived cell lineages. We also investigated whether p53-R248W/P72R-knockdown affected the expression of the most important stemness markers (Oct3/4, Nanog, Sox2, nucleostemin (NS) and CD133) that exhibited very high levels in untransfected $3 A B-$ OS cells. In Figs. 6B and 6C, western blot and real-time PCR analyses showed that p53-R248W/P72R-knockdown potently decreased the levels of all the analysed pluripotency markers. 
A

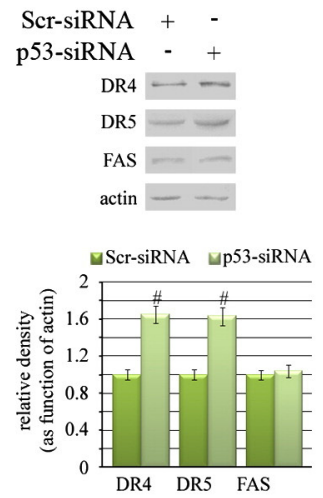

B $\begin{aligned} \text { Scr-siRNA } & - \\ \text { p53-siRNA } & - \\ \text { TRAIL } & -\end{aligned}$

Phase

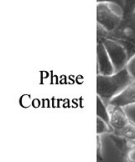

$-$
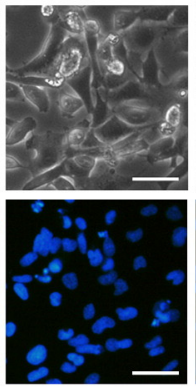
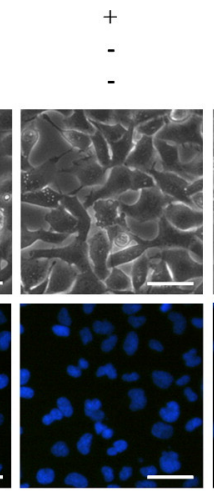

+
-
+
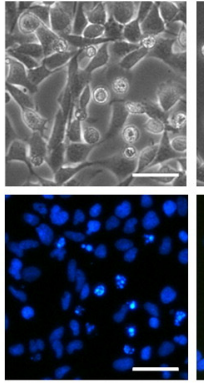
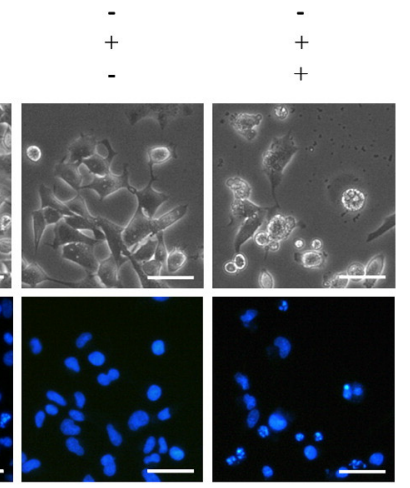

D
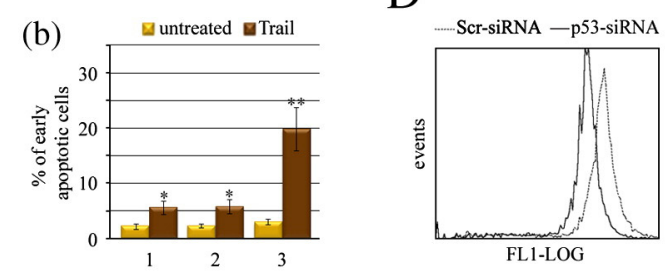

$\mathrm{E}$
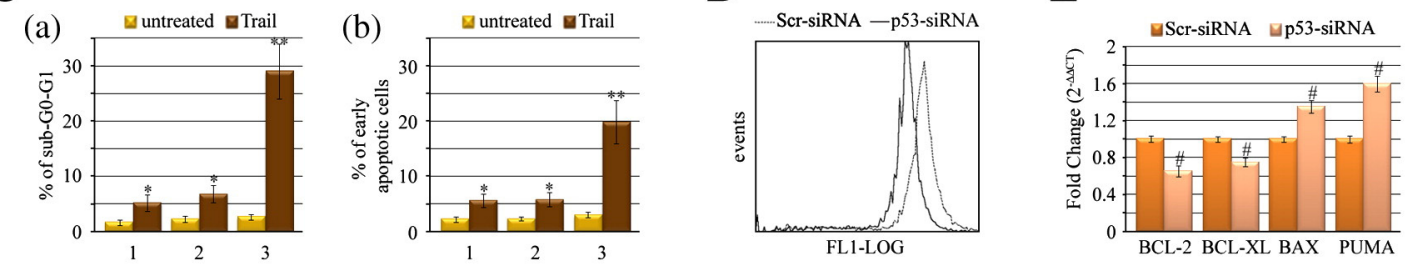

F

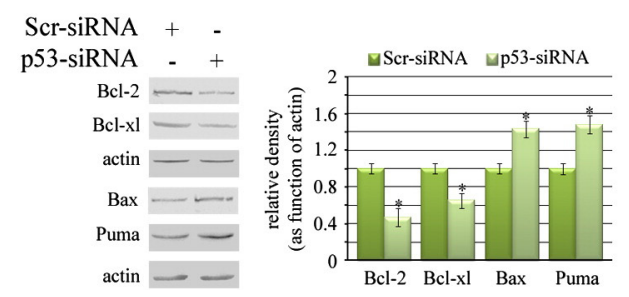

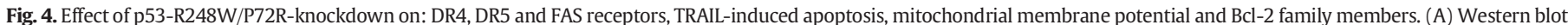

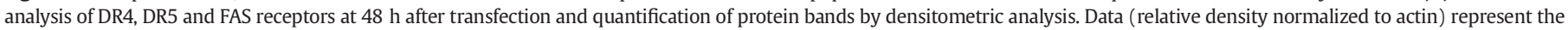

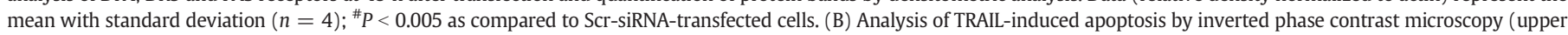

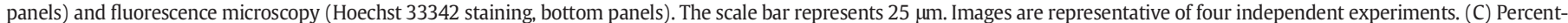

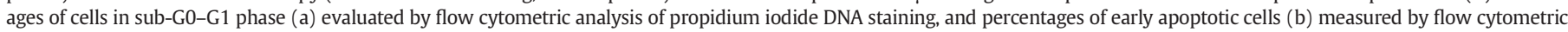

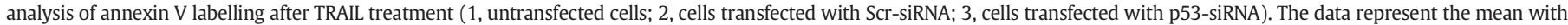

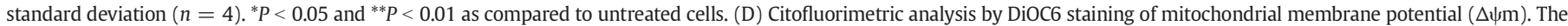

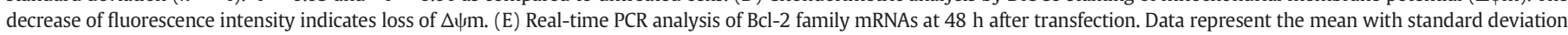

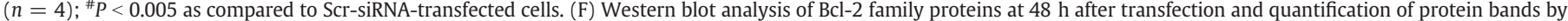
densitometric analysis. Data (relative density normalized to actin) represent the mean with standard deviation $(n=4)$; ${ }^{*} P<0.05$ as compared to Scr-siRNA-transfected cells.

\section{Ectopic expression of $p 53-R 248 \mathrm{~W} / \mathrm{P} 72 \mathrm{R}$ promotes cancer stem-like properties in osteosarcoma MG63 cells}

The above-described findings suggest that the GOF property of p53-R248W/P72R could be at the root of 3AB-OS stemness. To evaluate such a hypothesis, first-as reported in materials and methods-we produced a pcDNA3.1-vector containing p53-R248W/P72R; then, we stably transfected MG63 cells with either empty pcDNA3.1 vector or pcDNA3.1-p53-R248W/P72R. MG63 cells transfected with pcDNA3.1p53-R248W/P72R were designated R248W/P72R cells, while MG63 cells transfected with empty pcDNA3.1 vector were designated vector cells. Selected cells were then used to evaluate p53-R248W/P72R protein expression and localization. Western blot analysis (Fig. 7A) shows that, as expected, p53 protein was not detectable in vector cells, while it was expressed in R248W/P72R cells; in addition, flow cytometry analysis (Fig. 7B) shows a strong positivity for p53 (>75\%) in R248W/P72R cells. Immunofluorescence analysis shows the nuclear localization of p53 protein in R248W/P72R cells (Fig. 7C).

Thereafter, we evaluated in vitro whether p53-R248W/P72R expression in MG63 cells promotes cancer stem-like features, as high proliferation rate, sphere formation, clonogenic growth, high migration and invasive ability [35]. Initially, we compared the growth curves of R248W/P72R cells and vector cells. As shown in Fig. 7D, with respect to vector cells, R248W/P72R cells possess a higher proliferative output, exhibiting a doubling time of approximately $25 \mathrm{~h}$, whereas vector cells show a doubling time of $33 \mathrm{~h}$. This was confirmed by DNA content profiles-revealed by flow cytometry analysis of propidium iodide stained cells-showing that R248W/P72R cells were mostly in the S-G2|M phase, while vector cells were predominantly in G0|G1 (Fig. 7E).

It has been reported that cancer stem-like cells can be cultured in suspension to generate floating spheroid-like bodies under serum-free medium with bFGF and EGF [36]. Thus, we tested sarcosphereforming ability of R248W/P72R cells compared to vector cells. Fig. 7F shows that both vector and R248W/P72R cells were capable of forming sarcospheres. In particular, after 5 days in culture, vector cells formed sarcospheres having a mean diameter of $60.2 \pm 5.7 \mu \mathrm{m}$, at a frequency of approximately $1 / 54$ (9.3 \pm 1.5 spheres/500 cells), while R248W/P72R cells formed larger sarcospheres (mean diameter of $68.7 \pm 7.6 \mu \mathrm{m}$ ) at a frequency of approximately $1 / 42(12 \pm 2.0$ spheres/500 cells). After 10 days, R248W/P72R sarcospheres increased in size and number, having a mean diameter of $110 \pm 23 \mu \mathrm{m}$ and containing about 576 cells/sphere. Even vector sarcospheres increased in size and number, 
A

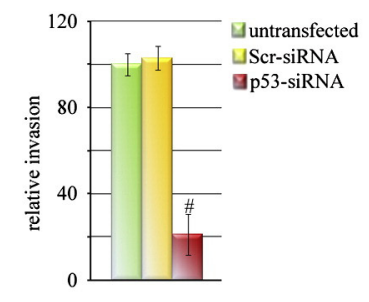

$\mathrm{C}$

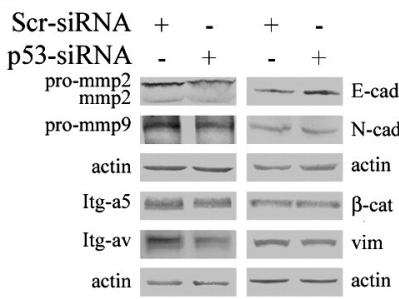

B
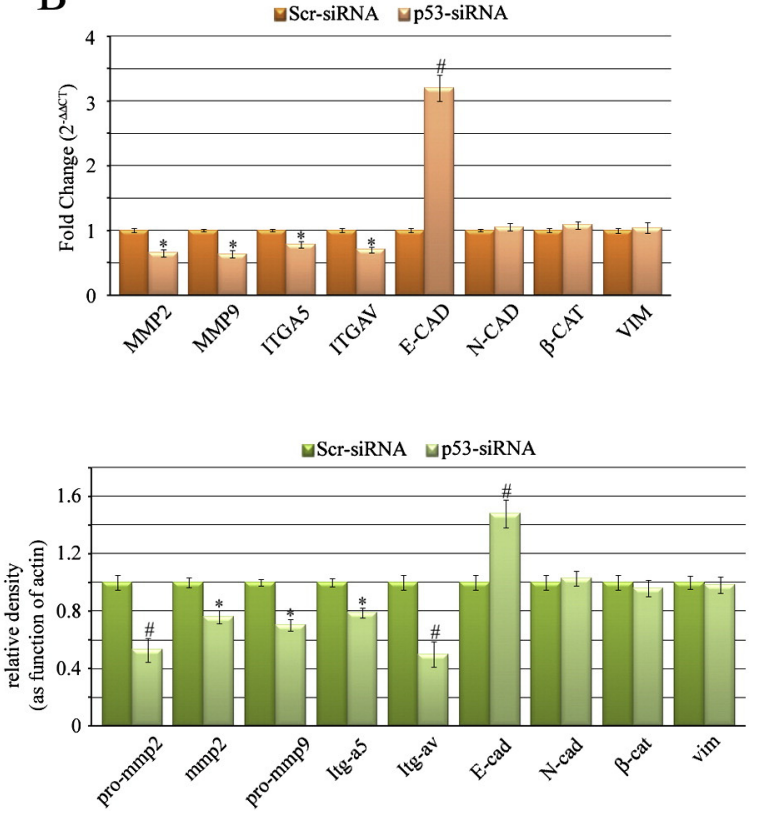

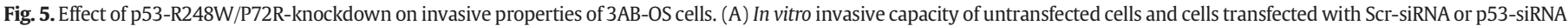

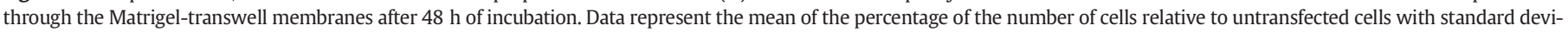

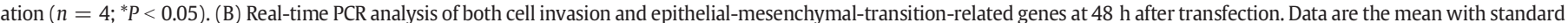

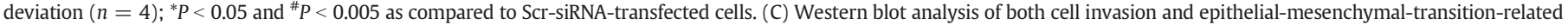

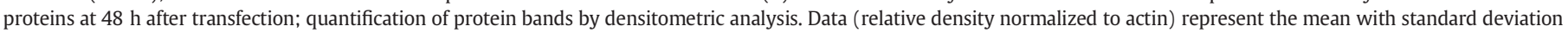
$(n=4) ;{ }^{*} P<0.05$ and ${ }^{\#} P<0.005$ as compared to Scr-siRNA-transfected cells.

but they were fewer in number and much smaller (mean diameter of $74.9 \pm 18.2 \mu \mathrm{m}$, containing about 214 cells/sphere). On analyzing sarcosphere-forming ability through subsequent passages $\left(2^{\circ}\right.$ and $3^{\circ}$ spheres), we found (Fig. 7G) that the number of sarcospheres generated from vector and R248W/P72R cells in each passage remained consistent; however, R248W/P72R cells formed $~ 2$-fold sarcospheres than vector cells, demonstrating their higher in vitro self-renewing potential. In addition, in a colony-forming assay that correlates with self renewal [37], R248W/P72R cells formed more numerous and larger colonies than vector cells (Fig. 7H).

We also examined the motility and invasivity of the cells in scratch/ wound healing and in Matrigel transwell invasion assays, respectively. Compared with vector cells, R248W/P72R cells showed higher migratory (Figs. 8A and 8B) and invasive (Figs. 8C and 8D) activity. These data suggest that $\mathrm{p} 53-\mathrm{R} 248 \mathrm{~W} / \mathrm{P} 72 \mathrm{R}$ expression can significantly promote the migratory and invasive function of MG63 cells.

To further determine whether R248W/P72R cells could express putative cancer stem cell markers, we chose to analyze by flow cytometry the expression profile of two representative stem cell surface markers of OS, CD133 and ABCG2 [11,35]. As shown in Fig. 8E, the cell surface expression of CD133 and ABCG2 was very low in both vector ( $0.7 \%$ and $1.5 \%$, respectively) and R248W/P72R (0.9\% and $4.3 \%$, respectively) cells. However, when we analyzed the CD133 and ABCG2 intracellular staining, we found a much higher intracellular positivity in both vector and R248W/P72R cells. In particular, as shown in Fig. 8F, R248W/P72R cells express a much higher percentage of CD133ABCG2-positivity (24.5\% and $88.3 \%$, respectively) than vector cells ( $8.3 \%$ and $63.1 \%$, respectively). In addition, western blot analyses for CD133 and ABCG2 show an up-regulation of both markers in R248W/ P72R cells, with an increase of 1.38-fold for CD133 and of 1.25-fold for ABCG2 with respect to vector cells (Fig. 8G). Furthermore, we investigated, by western blot analyses, the proteins regulating and maintaining the stem cell phenotype, as Nanog, OCT3/4, nucleostemin (NS) and Sox2. Interestingly, with respect to vector cells, Nanog, OCT3/4 and NS were found to significantly increase in R248W/P72R cells, with an increase of 1.56-fold, 1.22-fold and 1.37-fold for Nanog, OCT3/4 and NS, respectively (Fig. 8G). No significant change was observed in Sox2 level.

In the reported experiments, statistically significant difference was not observed in untransfected and vector cells.

\section{Discussion}

TP53 mutations occur in almost every type of cancer at rates varying between $10 \%$ in hematopoietic malignancies [38] and 98\% in high-grade serous carcinoma of the ovary [39]. Unlike the majority of tumor suppressor genes, which are inactivated by deletions or truncated mutations, TP53 mostly undergoes missense mutations [40]. These alterations produce a full-length mutp53 with a single amino acid substitution that loses its ability to bind DNA [41], induce apoptosis, inhibit growth and suppress transformation [42]. Mutp53 is stable, its accumulation is regarded as a hallmark of cancer [43], and in most cases it not only loses its tumor-suppressive activities but also gains oncogenic functions [44]. In OS patients, alterations of TP53 occurs in 50\%-60\% of cases and consist of point mutations (20\%-30\%, mostly missense mutations), gross gene rearrangements (10\%-20\%) and allelic loss (75\%-80\%) [1], with its mutation status serving as a valuable indicator for predicting chemoresistance [45]. Accordingly, patients with Li-Fraumeni syndrome, a disorder characterized by a germline mutation at the p53 locus, have a significantly higher risk of developing OS [46].

In this study, we investigated the TP53 gene status/role of human 3AB-OS CSCs compared with parental MG63 cells. We demonstrated that in MG63 cells, where TP53 is not expressed and in single copy [47], the gene does not colocalize on chromosome 17 and is endowed with a methylated promoter. Instead, $3 \mathrm{AB}-\mathrm{OS}$ cells strongly express a $\mathrm{p} 53$ protein ( $\mathrm{p} 53-\mathrm{R} 248 \mathrm{~W} / \mathrm{P} 72 \mathrm{R}$ ) whose TP53 gene is rearranged and in multiple copies characterized by P72R polymorphism and hot spot mutation R248W. It has been reported that TP53 mutations strongly predominate in exons 4-9 most of which fall within 6 "hotspot" residues (R175, G245, R248, R249, R273 and R282) in almost all types of 
A
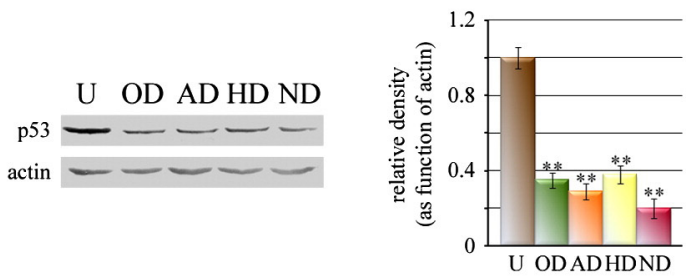

B
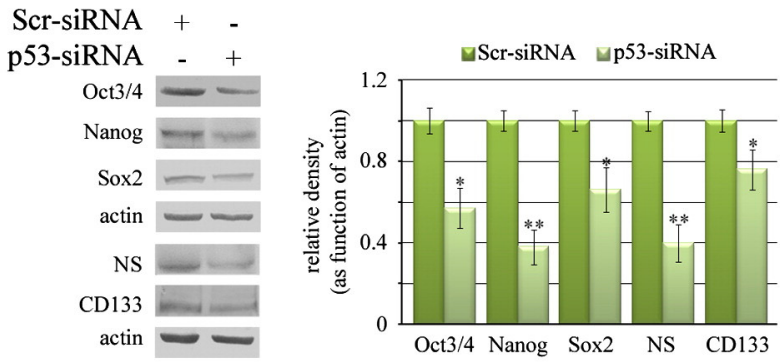

C

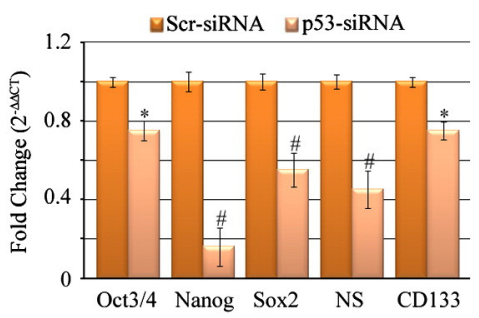

Fig. 6. Effect of p53-R248W/P72R-knockdown on various stem-cell markers in 3AB-OS cells. (A) Western blot analysis of p53-R248W/P72R in undifferentiated (U) and differentiated 3AB-OS cells (see below the abbreviations for derived cell lineages) and quantification of protein bands by densitometric analysis. Data (relative density normalized to actin) represent the mean with standard deviation $(n=4) ;{ }^{* *} P<0.01$ as compared to undifferentiated cells. Abbreviations: OD, osteogenic differentiation; AD, adipogenic differentiation; HD, hepatogenic differentiation; ND, neurogenic differentiation. (B) Western blot analysis of stemness proteins at $48 \mathrm{~h}$ after transfection and quantification of protein bands by densitometric analysis. The data (relative density normalized to actin) represent the mean with standard deviation $(n=4) ;{ }^{*} P<0.05$ and ${ }^{* *} P<0.01$ as compared to Scr-siRNA-transfected cells. (C) Real-time PCR analysis of stemness genes at $48 \mathrm{~h}$ after transfection. Data represent the mean with standard deviation $(n=4) ;{ }^{*} P<0.05$ and ${ }^{\#} P<0.005$ as compared to ScrsiRNA-transfected cells.

cancer [48]. Intriguingly, OS patients carrying TP53 hot spot mutations (most regarding codon 248) were found to have a significantly increased death risk [49].

It is well known that wild-type $\mathrm{p} 53$ is regulated by post-translational modifications as phosphorylation at Ser15 (required for its stabilization [50] and interaction with transcriptional co-activators) and acetylation at Lys320, 373 and 382 (required for both its transcriptional activity and its transcription-independent proapoptotic function [51,52]). Although it has been observed that in UV-induced mouse skin tumors mutp53 is phosphorylated at Ser15 and accumulated exclusively to the nucleus [53], up to now little is known about post-translational modifications of mutp53 in human OS cell lines or patients. Herein, we show that in 3AB-OS cells p53-R248W/P72R is constitutively modified by both phosphorylation at Ser15 and acetylation at Lys320, 373 and 382, and it is localized to the nucleus.

Our results also demonstrated that p53-R248W/P72R-knockdown strongly reduces the growth and replication rate of $3 \mathrm{AB}-\mathrm{OS}$ cells and concomitantly increases the expression of genes, inhibiting cell cycle progression (pRb, p130, p107, E2F4, GADD45, p21 and p27) while lowering CDK4, the activator of the cell cycle progression through $\mathrm{G} 1 / \mathrm{S}$ phase. The findings are in accordance with alteration of genes involved in cell cycle seen in up to $80 \%$ of pediatric/adult OS patients [54-56], which demonstrate that genetic lesions deregulating $\mathrm{G} 1 / \mathrm{S}$ cell cycle checkpoint may be a constant feature in the pathogenesis of OS.

Another distinctive feature of mutp53 is its ability to confer on cells an elevated resistance to a variety of apoptotic signals [44]. Studies designed to investigate the prognostic significance of bax and bcl-2 expression in surgically treated OS patients demonstrate that a high $\operatorname{bax}(+) / \mathrm{bcl}-2(-)$ protein expression ratio is associated with an unfavourable outcome in patients with primary OS, with this coexpression pattern probably counterbalancing the accelerated proliferation status of the malignant cells and indirectly characterizing a more aggressive tumor [57]. Moreover, analyses of death receptors in OS samples and in OS cell lines-among which MG63 cells-demonstrated alterations only within the DR4 gene, suggesting that these genetic alterations may be implicated in OS formation [58]. We have previously shown that $3 \mathrm{AB}-\mathrm{OS}$ cells highly express a great number of genes required for inhibiting apoptosis [11] and much lower levels of FAS and DR4 receptors than parental MG63 cells [14]. Here we show that in 3AB-OS cells p53-R248W/P72R-knockdown potently increases the expression of DR4 and DR5 receptors and sensitivity to TRAIL-induced apoptosis. Since, as above reported, DR4 receptor is mutated in parental MG63 cells, we maintain that $3 \mathrm{AB}-\mathrm{OS}$ cells can carry such a mutation and suggest that sensitivity to TRAIL-induced apoptosis in p53-R248W/ P72R-knockdown cells could arise from DR5 receptor up-regulation. Overall, this finding, together with the observation that p53-R248W/ P72R-knockdown markedly increased the levels of the proapoptotic factors Bax and Puma while decreased those of the antiapoptotic factors $\mathrm{Bcl}-2$ and Bcl-XL, suggests that in 3AB-OS cells p53-R248W/P72R could hinder cell response to TRAIL-treatment.

Stemness acquisition is a key event in cancer development as it may induce progression, invasion, dissemination and metastasis. OS is a highly metastatic tumor with metastases being the major cause of death, and in patients with high-grade OS, increased MMP expression was identified as prognostic marker for poor outcome [59,60]. Herein, we show that p53-R248W/P72R-knockdown causes a striking reduction of in vitro invasive capacity of 3AB-OS cells with a decrease of the invasion-related gene and protein (MMP2, MMP9, ITG $\alpha 5$ and ITG $\alpha$ V) levels and a concomitant marked increase in E-cadherin. This suggests that the oncogenic properties of p53-R248W/P72R could also enable $3 \mathrm{AB}-\mathrm{OS}$ cells to promote invasion.

Recently Sarig et al. [61] reported a novel GOF property for mutp53, which markedly enhanced the efficiency of the reprogramming process compared with p53 deficiency. This novel activity of mutp53 induced alterations in the characteristics of the reprogrammed cells. Indeed, although p53-knockout cells reprogrammed with Oct4 and Sox2 maintained their pluripotent capacity in vivo, reprogrammed cells expressing mutp53 lost this capacity and gave rise to malignant tumors.

Since osteosarcomas contain highly proliferative malignant cells that are largely arrested in their differentiation, OS is proposed to be a "differentiation-flawed disease," resulting from genetic and epigenetic disruption of the osteoblast differentiation pathway [1]. Moreover, the presence of OS stem-like cells has been reported in patient tumors [62] as well as in established human OS cell lines [63]. We have previously shown $[11,13,14]$ that 3 AB-OS cells highly express a large panel of stemness-related genes/proteins and that efficiently transdifferentiate in vitro into cells of all the three primary germ layers [12], whereas when $3 A B-O S$ cells were engrafted in nude mice, they potently induced malignant tumors, although preserving multilineage commitment [13]. Here, we show that, after in vitro 3AB-OS differentiation, in each derived cell lineage, p53-R248W/P72R was profoundly down-regulated and after p53-R248W/P72R-knockdown the expression of pluripotent markers (Oct3/4, Nanog, Sox2, nucleostemin and CD133) markedly lowered, suggesting that p53-R248W/P72R might be responsible for 3AB-OS cells pluripotency and self-renewal. 
A

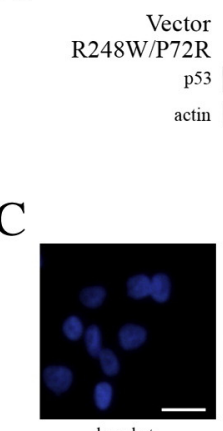

hoechst
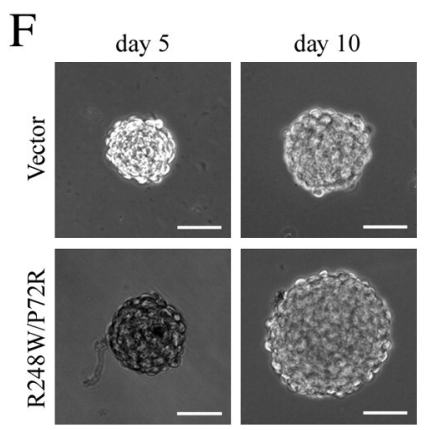

day 10
B

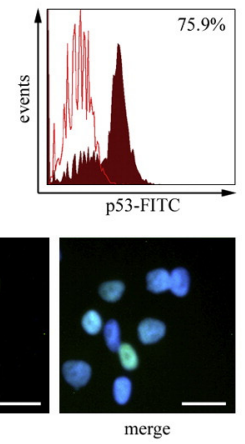

$\mathrm{D}$

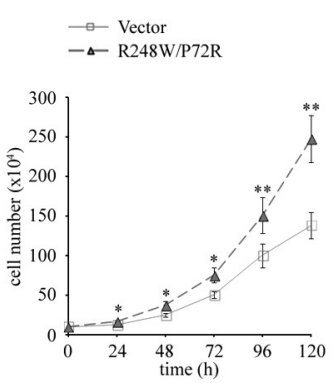

E

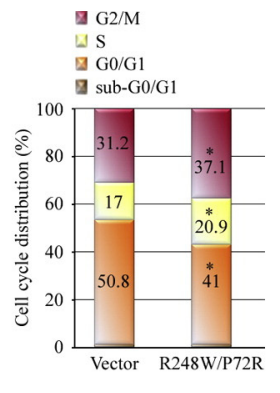

$\mathrm{H}$
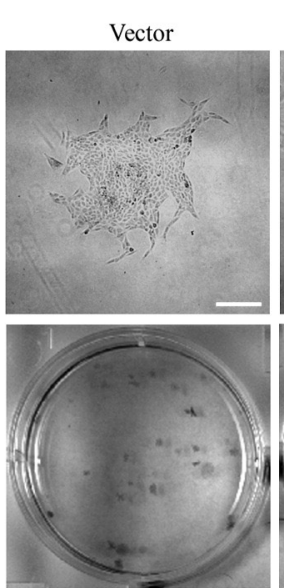
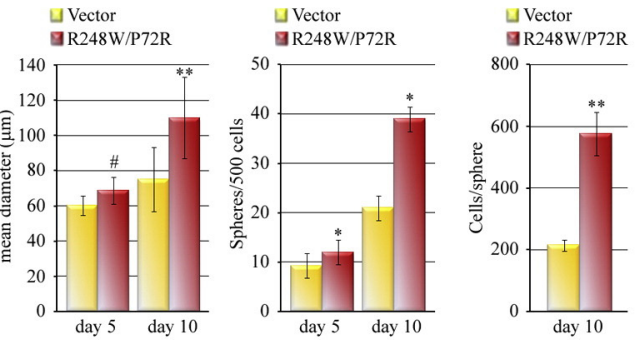

G

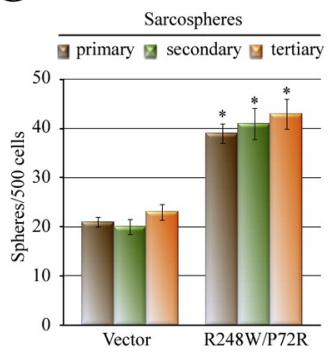

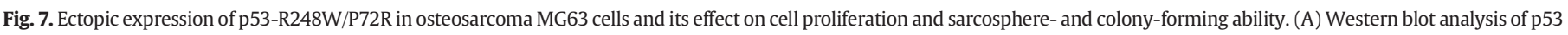

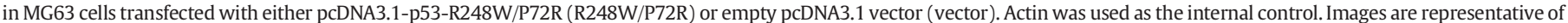

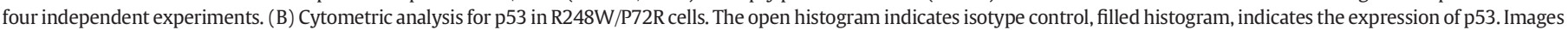

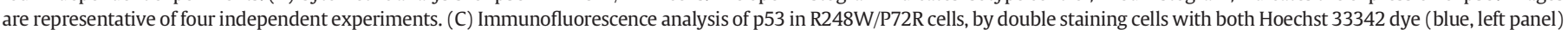

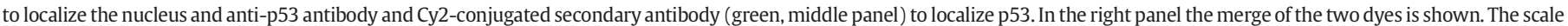

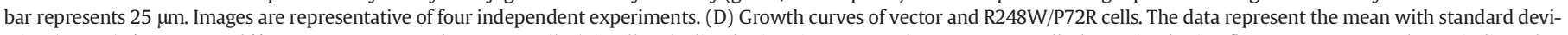

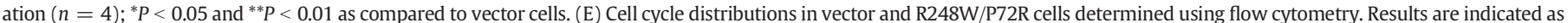

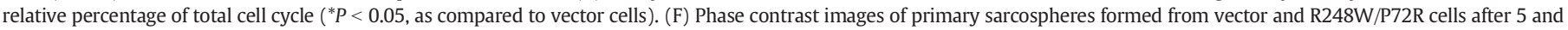

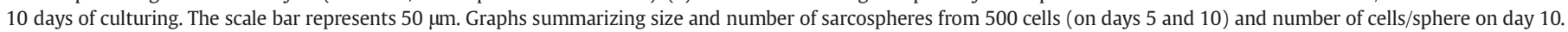

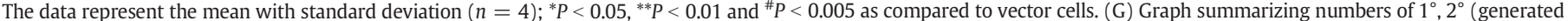

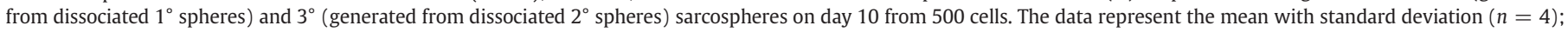

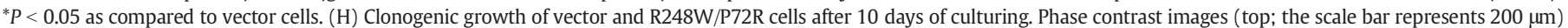

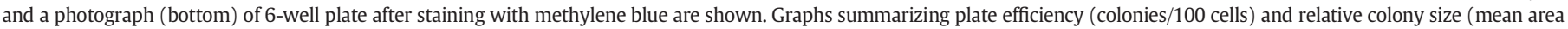
relative to vector cells). The data represent the mean with standard deviation $(n=4)$; ${ }^{* *} P<0.01$ and ${ }^{\#} P<0.005$ as compared to vector cells.

Here, we also show that the ectopic expression of p53-R248W/P72R promotes cancer stem-like properties in osteosarcoma MG63 parental cells. Indeed, when MG63 cells were transfected with pcDNA3.1-p53R248W/P72R, R248W/P72R cells showed strong positivity for p53 and its nuclear localization. Moreover, R248W/P72R cells, with respect to vector cells, showed a higher proliferative output, were capable of forming 2 -fold sarcospheres, formed more numerous and larger colonies and showed higher migratory and invasive activity. In addition, R248W/ P72R cells showed significant increase in the expression of stemness markers.

In conclusion, the findings that in 3AB-OS cells p53-R248W/P72Rknockdown profoundly changed the expression of genes/proteins correlated to stemness, proliferation, apoptosis and invasiveness, and that in MG63 parental cells, the ectopic expression of p53-R248W/ 
A

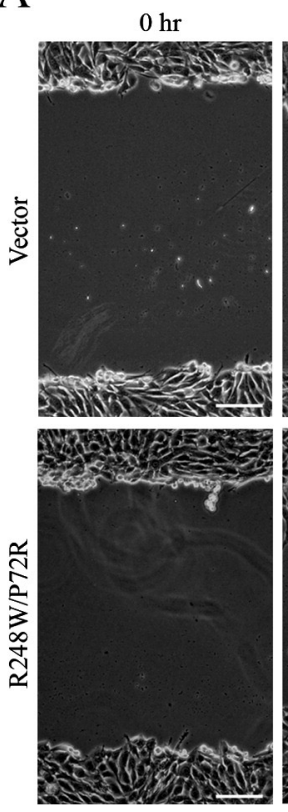

$\mathrm{E}$

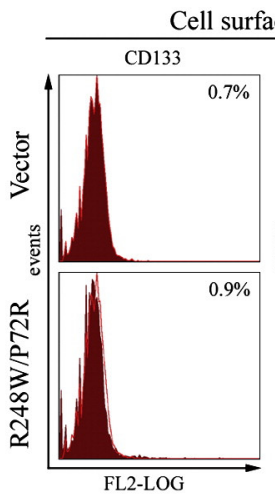

$8 \mathrm{hr}$
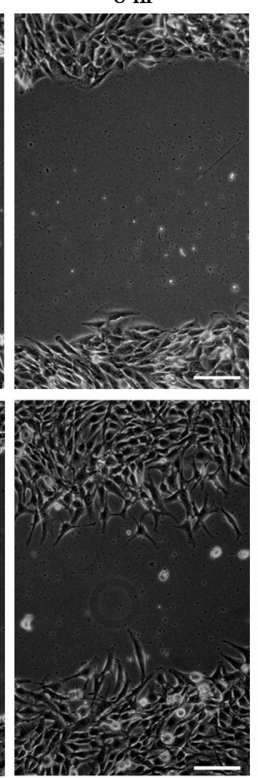

$24 \mathrm{hr}$
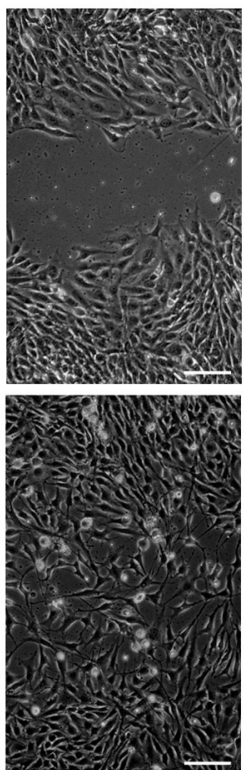

B

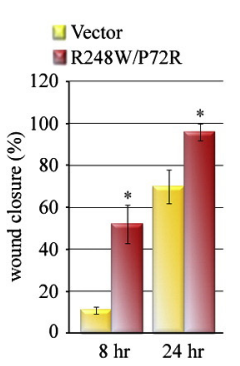

C

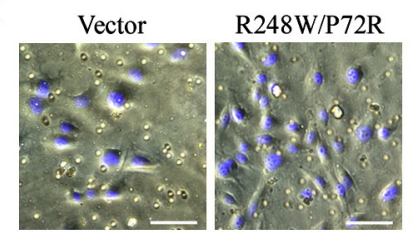

$\mathrm{D}$

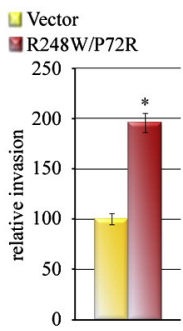

F

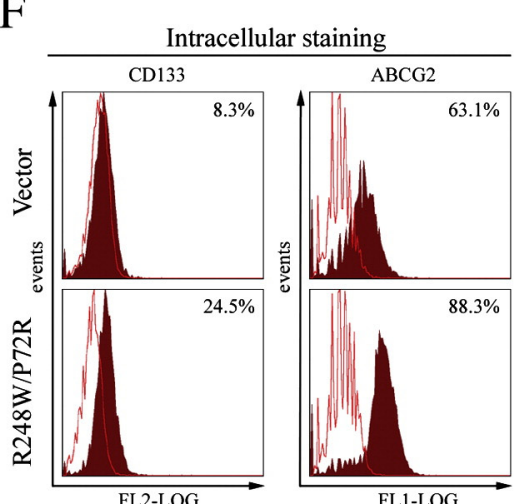

G
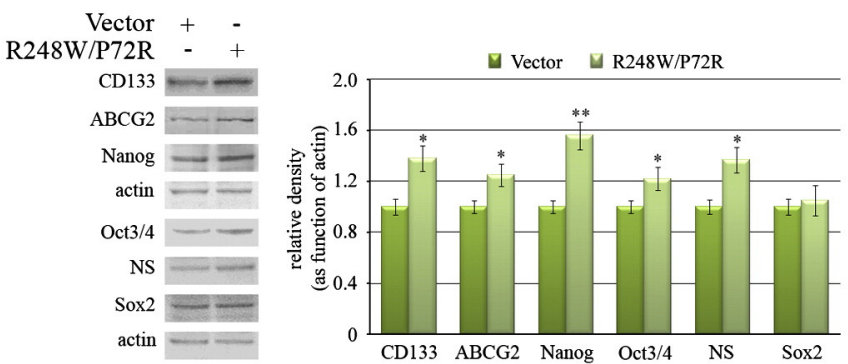

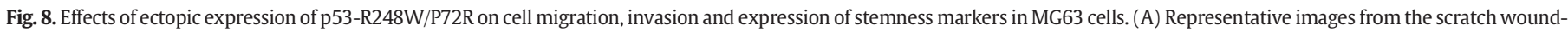

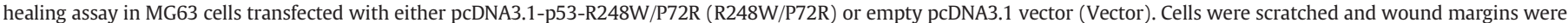

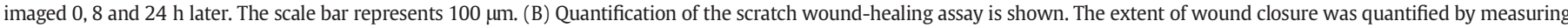

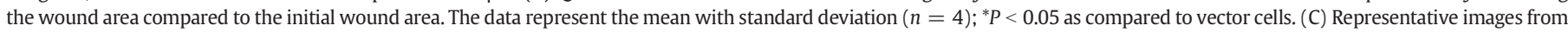

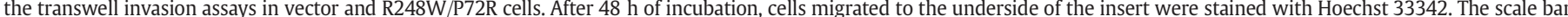

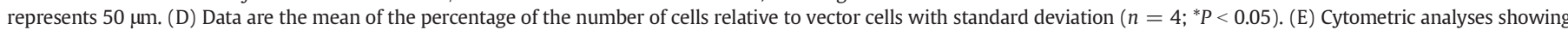

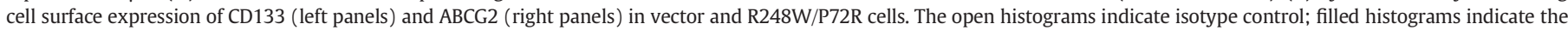

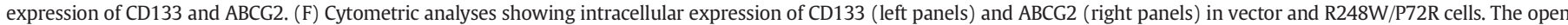

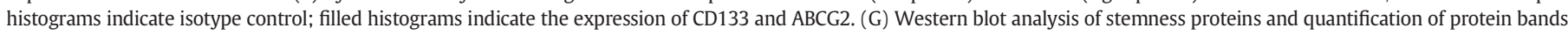
by densitometric analysis. The data (relative density normalized to actin) represent the mean with standard deviation $(n=4)$; ${ }^{*} P<0.05$ and ${ }^{* *} P<0.01$ as compared to vector cells.

P72R promoted cancer stem-like properties, suggest that the GOF property of p53-R248W/P72R can be at the root of the dedifferentiation of MG63 cells into 3AB-OS CSCs. We believe that 3AB-OS cells could provide a best-fit to understand p53-R248W/P72R properties and its potential involvement in osteosarcomagenesis.

\section{Acknowledgments}

We thank Dr. Francesca Malvestiti (Research and Development Area-Toma Advanced Biomedical Assays S.p.A., Busto Arsizio, VA, Italy) for her helpful technical discussion on FISH analysis. We also 
thank Dr. Giulia Malferrari laboratory Responsible at BioRep S.r.l. (Milano, Italy) for her technical help on DNA sequence analysis.

This work was partially funded by the European Regional Development Fund, European Territorial Cooperation 2007-2013, CCI 2007 CB 163 PO 037, OP Italia-Malta 2007-2013; the Italian Ministry of Education, University and Research (MIUR) ex-60\%, 2013; and the MIUR-PRIN, contract number 2008P8BLNF (2008). R. Di Fiore was a recipient of a fellowship granted by MIUR (contract number 867/06/07/2011); D. Carlisi was a recipient of a fellowship granted by MIUR (contract number 2223/12/19/2011); R. Drago-Ferrante was a recipient of a fellowship granted by MIUR-PRIN (contract number 144/01/26/2012); M. Marcatti and F. Querques are PhD students supported by Italian Ministry of Education, University and Research (MIUR).

The authors declare no conflict of interest.

\section{Appendix A. Supplementary data}

Supplementary data to this article can be found online at http:// dx.doi.org/10.1016/j.bone.2013.12.021.

\section{References}

[1] Tang N, Song WX, Luo J, Haydon RC, He TC. Osteosarcoma development and stem cell differentiation. Clin Orthop Relat Res 2008;8:2114-30.

[2] Chou AJ, Gorlick R. Chemotherapy resistance in osteosarcoma: current challenges and future directions. Expert Rev Anticancer Ther 2006;6:1075-85.

[3] Clevers H. The cancer stem cell: premises, promises and challenges. Nat Med 2011;17:313-9.

[4] Li L, Neaves WB. Normal stem cells and cancer stem cells: the niche matters. Cancer Res 2006;66:4553-7.

[5] Maitland NJ, Collins AT. Prostate cancer stem cells: a new target for therapy. J Clin Oncol 2008;26:2862-70.

[6] Bapat SA. Evolution of cancer stem cells. Semin Cancer Biol 2007;17:204-13.

[7] Frank NY, Schatton T, Frank MH. The therapeutic promise of the cancer stem cell concept. J Clin Invest 2010;120:41-50.

[8] Morrison R, Schleicher SM, Sun Y, Niermann KJ, Kim S, Spratt DE, et al. Targeting the mechanisms of resistance to chemotherapy and radiotherapy with the cancer stem cell hypothesis. J Oncol 2011;2011:941876.

[9] Prud'homme GJ. Cancer stem cells and novel targets for antitumor strategies. Curr Pharm Des 2012;18:2838-49.

[10] De Blasio A, Messina C, Santulli A, Mangano V, Di Leonardo E, D'Anneo A, et al. Differentiative pathway activated by 3 -aminobenzamide, an inhibitor of PARP, in human osteosarcoma MG63 cells. FEBS Lett 2005;579:615-20.

[11] Di Fiore R, Santulli A, Drago-Ferrante R, Giuliano M, De Blasio A, Messina C, et al. Identification and expansion of human osteosarcoma-cancer-stem cells by longterm 3-aminobenzamide treatment. J Cell Physiol 2009;219:301-13.

[12] Di Fiore R, Drago-Ferrante R, D'Anneo A, De Blasio A, Santulli A, Messina C, et al. Differentiation of human osteosarcoma 3AB-OS stem-like cells in derivatives of the three primary germ layers as an useful in vitro model to develop several purposes. Stem Cell Discov 2013:3:188-201.

[13] Di Fiore R, Guercio A, Puleio R, Di Marco P, Drago-Ferrante R, D'Anneo A, et al. Modeling human osteosarcoma in mice through 3AB-OS cancer stem cell xenografts. J Cell Biochem 2012;113:3380-92.

[14] Di Fiore R, Fanale D, Drago-Ferrante R, Chiaradonna F, Giuliano M, De Blasio A, et al. Genetic and molecular characterization of the human osteosarcoma 3AB-OS cancer stem cell line: a possible model for studying osteosarcoma origin and stemness. Cell Physiol 2013:228:1189-201.

[15] Bridge JA, Nelson M, McComb E, McGuire MH, Rosenthal H, Vergara G, et al. Cytogenetic findings in 73 osteosarcoma specimens and a review of the literature. Cancer Genet Cytogenet 1997;95:74-87.

[16] Batanian JR, Cavalli LR, Aldosari NM, Ma E, Sotelo-Avila C, Ramos MB, et al. Evaluation of paediatric osteosarcomas by classic cytogenetic and CGH analyses. Mol Pathol 2002;55:389-93.

[17] Niini T, Lahti L, Michelacci F, Ninomiya S, Hattinger CM, Guled M, et al. Array comparative genomic hybridization reveals frequent alterations of G1/S checkpoint genes in undifferentiated pleomorphic sarcoma of bone. Genes Chromosomes Cancer 2011;50:291-306.

[18] Adorno M, Cordenonsi M, Montagner M, Dupont S, Wong C, Hann B, et al. A mutantp53/Smad complex opposes p63 to empower $\mathrm{TGF}^{2}$-induced metastasis. Cell 2009;137:87-98.

[19] Muller PA, Caswell PT, Doyle B, Iwanicki MP, Tan EH, Karim S, et al. Mutant p53 drives invasion by promoting integrin recycling. Cell 2009;139:1327-41.

[20] Bossi G, Lapi E, Strano S, Rinaldo C, Blandino G, Sacchi A. Mutant p53 gain of function: reduction of tumor malignancy of human cancer cell lines through abrogation of mutant p53 expression. Oncogene 2006;25:304-9.

[21] Dittmer D, Pati S, Zambetti G, Chu S, Teresky AK, Moore M, et al. Gain of function mutations in p53. Nat Genet 1993;4:42-6.

[22] Sigal A, Rotter V. Oncogenic mutations of the p53 tumor suppressor: the demons of the guardian of the genome. Cancer Res 2000;60:6788-93.
[23] Scian MJ, Stagliano KE, Anderson MA, Hassan S, Bowman M, Miles MF, et al. Tumorderived p53 mutants induce NF-kappaB2 gene expression. Mol Cell Biol 2005;25: 10097-110.

[24] Blandino G, Levine AJ, Oren M. Mutant p53 gain of function: differential effects of different p53 mutants on resistance of cultured cells to chemotherapy. Oncogene 1999; 18:477-85

[25] Song H, Hollstein M, Xu Y. p53 gain-of-function cancer mutants induce genetic instability by inactivating ATM. Nat Cell Biol 2007;9:573-80.

[26] Xu Y. Induction of genetic instability by gain-of-function p53 cancer mutants. Oncogene 2008;27:3501-7.

[27] Noll JE, Jeffery J, Al-Ejeh F, Kumar R, Khanna KK, Callen DF, et al. Mutant p53 drives multinucleation and invasion through a process that is suppressed by ANKRD11. Oncogene 2012;31:2836-48.

[28] Spike BT, Wahl GM. p53, stem cells, and reprogramming: tumor suppression beyond guarding the genome. Genes Cancer 2011;2:404-19.

[29] De Blasio A, Musmeci MT, Giuliano M, Lauricella M, Emanuele S, D'Anneo A, et al. The effect of 3-aminobenzamide, inhibitor of poly(ADP-ribose) polymerase, on human osteosarcoma cells. Int J Oncol 2003;23:1521-8.

[30] Gawrychowski J, Lackowska B, Gabriel A. Prognosis of the surgical treatment of patients with non-small cell lung cancer (NSCLC)-relation to DNA ploidy. Eur J Cardiothorac Surg 2003;23:870-7.

[31] Kang JH, Kim SJ, Noh DY, Park IA, Choe KJ, Yoo OJ, et al. Methylation in the p53 promoter is a supplementary route to breast carcinogenesis: correlation between CpG methylation in the p53 promoter and the mutation of the p53 gene in the progression from ductal carcinoma in situ to invasive ductal carcinoma. Lab Invest 2001;81:573-9.

[32] Amatya VJ, Naumann U, Weller M, Ohgaki H. TP53 promoter methylation in human gliomas. Acta Neuropathol 2005;110:178-84

[33] Agirre X, Vizmanos JL, Calasanz MJ, García-Delgado M, Larráyoz MJ, Novo F. Methylation of CpG dinucleotides and/or CCWGG motifs at the promoter of TP53 correlates with decreased gene expression in a subset of acute lymphoblastic leukemia patients. Oncogene 2003;22:1070-2.

[34] Pogribny IP, James SJ. Reduction of p53 gene expression in human primary hepatocellular carcinoma is associated with promoter region methylation without coding region mutation. Cancer Lett 2002;176:169-74.

[35] Tirino V, Desiderio V, d'Aquino R, De Francesco F, Pirozzi G, Graziano A, et al. Detection and characterization of CD133 + cancer stem cells in human solid tumours. PLoS One 2008;3:e3469.

[36] Lee J, Kotliarova S, Kotliarov Y, Li A, Su Q, Donin NM, et al. Tumor stem cells derived from glioblastomas cultured in bFGF and EGF more closely mirror the phenotype and genotype of primary tumors than do serum-cultured cell lines. Cancer Cell 2006;9:391-403.

[37] Patrawala L, Calhoun T, Schneider-Broussard R, Zhou J, Claypool K, Tang DG. Side population is enriched in tumorigenic, stem-like cancer cells, whereas ABCG2 + and ABCG2- cancer cells are similarly tumorigenic. Cancer Res 2005;65: 6207-19.

[38] Peller S, Rotter V. TP53 in hematological cancer: low incidence of mutations with significant clinical relevance. Hum Mutat 2003;21:277-84.

[39] Ahmed AA, Etemadmoghadam D, Temple J, Lynch AG, Riad M, Sharma R, et al. Driver mutations in TP53 are ubiquitous in high grade serous carcinoma of the ovary. J Pathol 2010;221:49-56.

[40] Hainaut P, Hollstein M. p53 and human cancer: the first ten thousand mutations. Adv Cancer Res 2000;77:81-137.

[41] Bullock AN, Fersht AR. Rescuing the function of mutant p53. Nat Rev Cancer 2001;1: $68-76$.

[42] Hollstein M, Sidransky D, Vogelstein B, Harris CC. p53 mutations in human cancers. Science 1991;253:49-53.

[43] Rivlin N, Brosh R, Oren M, Rotter V. Mutations in the p53 tumor suppressor gene: important milestones at the various steps of tumorigenesis. Genes Cancer 2011;2: 466-74.

[44] Oren M, Rotter V. Mutant p53 gain-of-function in cancer. Cold Spring Harb Perspect Biol 2010;2:a001107.

[45] Petitjean A, Mathe E, Kato S, Ishioka C, Tavtigian SV, Hainaut P, et al. Impact of mutant p53 functional properties on TP53 mutation patterns and tumor phenotype: lessons from recent developments in the IARC TP53 database. Hum Mutat 2007;28: 622-9.

[46] Malkin D, Jolly KW, Barbier N, Look AT, Friend SH, Gebhardt MC, et al. Germline mutations of the p53 tumor-suppressor gene in children and young adults with second malignant neoplasms. N Engl J Med 1992;326:1309-15.

[47] Masuda H, Miller C, Koeffler HP, Battifora H, Cline MJ. Rearrangement of the p53 gene in human osteogenic sarcomas. Proc Natl Acad Sci U S A 1987:84:7716-9.

[48] Cho Y, Gorina S, Jeffrey PD, Pavletich NP. Crystal structure of a p53 tumor suppressorDNA complex: understanding tumorigenic mutations. Science 1994;265:346-55.

[49] Gokgoz N, Wunder JS, Mousses S, Eskandarian S, Bell RS, Andrulis IL. Comparison of p53 mutations in patients with localized osteosarcoma and metastatic osteosarcoma. Cancer 2001;92:2181-9.

[50] Shieh SY, Ikeda M, Taya Y, Prives C. DNA damage-induced phosphorylation of p53 alleviates inhibition by MDM2. Cell 1997;91:325-34.

[51] Luo J, Li M, Tang Y, Laszkowska M, Roeder RG, Gu W. Acetylation of p53 augments its site-specific DNA binding both in vitro and in vivo. Proc Natl Acad Sci U S A 2004;101: 2259-64.

[52] Caelles C, Helmberg A, Karin M. p53-dependent apoptosis in the absence of transcriptional activation of p53-target genes. Nature 1994;370:220-323.

[53] Melnikova VO, Santamaria AB, Bolshakov SV, Ananthaswamy HN. Mutant p53 is constitutively phosphorylated at Serine 15 in UV-induced mouse skin tumors: involvement of ERK1/2 MAP kinase. Oncogene 2003;22:5958-66. 
[54] Wei G, Lonardo F, Ueda T, Kim T, Huvos AG, Healey JH, et al. CDK4 gene amplification in osteosarcoma: reciprocal relationship with INK4A gene alterations and mapping of 12q13 amplicons. Int J Cancer 1999;80:199-204.

[55] Lonardo F, Ueda T, Huvos AG, Healey J, Ladanyi M. p53 and MDM2 alterations in osteosarcomas: correlation with clinicopathologic features and proliferative rate. Cancer 1997;79:1541-7.

[56] Nielsen GP, Burns KL, Rosenberg AE, Louis DN. CDKN2A gene deletions and loss of p16 expression occur in osteosarcomas that lack RB alterations. Am J Pathol 1998;153:159-63.

[57] Kaseta MK, Khaldi L, Gomatos IP, Tzagarakis GP, Alevizos L, Leandros E, et al. Prognostic value of bax, bcl-2, and p53 staining in primary osteosarcoma. J Surg Oncol 2008;97:259-66.

[58] Dechant MJ, Fellenberg J, Scheuerpflug CG, Ewerbeck V, Debatin KM. Mutation analysis of the apoptotic "death-receptors" and the adaptors TRADD and FADD/MORT-1 in osteosarcoma tumor samples and osteosarcoma cell lines. Int J Cancer 2004;109:661-7.
[59] Bjørnland K, Flatmark K, Pettersen S, Aaasen AO, Fodstad O, Maelandsmo GM. Matrix metalloproteinases participate in osteosarcoma invasion. J Surg Res 2005;127: 151-6.

[60] Ferrari C, Benassi S, Ponticelli F, Gamberi G, Ragazzini P, Pazzaglia L, et al. Role of MMP-9 and its tissue inhibitor TIMP-1 in human osteosarcoma: findings in 42 patients followed for 1-16 years. Acta Orthop Scand 2004;75: 487-91.

[61] Sarig R, Rivlin N, Brosh R, Bornstein C, Kamer I, Ezra O, et al. Mutant p53 facilitates somatic cell reprogramming and augments the malignant potential of reprogrammed cells. J Exp Med 2010;207:2127-40.

[62] Tirino V, Desiderio V, Paino F, De Rosa A, Papaccio F, Fazioli F, et al. Human primary bone sarcomas contain CD133 + cancer stem cells displaying high tumorigenicity in vivo. FASEB J 2011;25:2022-30.

[63] Wang L, Park P, Lin CY. Characterization of stem cell attributes in human osteosarcoma cell lines. Cancer Biol Ther 2009;8:543-52. 